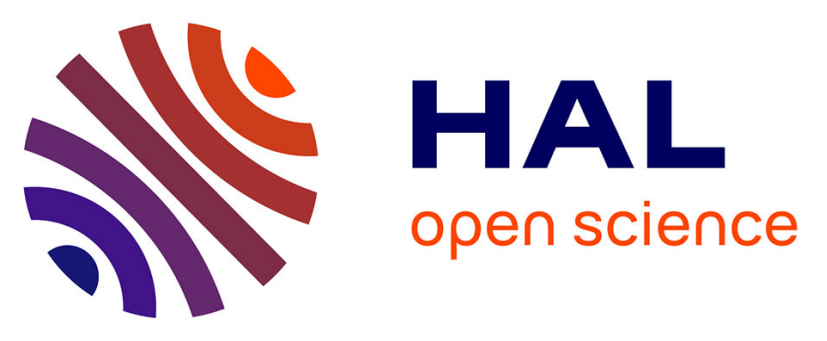

\title{
The Bronze Age decorated cave Les Fraux unusual status: ritual uses of an atypical French heritage site
}

Albane Burens-Carozza, Laurent Carozza, Raphaelle Bourrillon, Stephane Petrognani, Pierre Grussenmeyer, Samuel Guillemin, Francois Leveque, Vivien Mathé, Yves Billaud, Aurélie Brodard, et al.

\section{To cite this version:}

Albane Burens-Carozza, Laurent Carozza, Raphaelle Bourrillon, Stephane Petrognani, Pierre Grussenmeyer, et al.. The Bronze Age decorated cave Les Fraux unusual status: ritual uses of an atypical French heritage site. Lindsey Büster; Eugène Warmenbol; Dimitrij Mlekuž. Between worlds: understanding ritual cave use in later prehistory, Springer, pp.165-198, 2019, 10.1007/978-3-319-99022-4_9 . hal-02014449

\section{HAL Id: hal-02014449 \\ https://hal.science/hal-02014449}

Submitted on 9 Nov 2020

HAL is a multi-disciplinary open access archive for the deposit and dissemination of scientific research documents, whether they are published or not. The documents may come from teaching and research institutions in France or abroad, or from public or private research centers.
L'archive ouverte pluridisciplinaire HAL, est destinée au dépôt et à la diffusion de documents scientifiques de niveau recherche, publiés ou non, émanant des établissements d'enseignement et de recherche français ou étrangers, des laboratoires publics ou privés. 


\title{
Chapter 9
}

\section{The Bronze Age Decorated Cave of Les}

\begin{abstract}
Albane Burens, Laurent Carozza, Raphaelle Bourrillon, Stephane Petrogani, 5 Pierre Grussenmeyer, Samuel Guillemin, François Lévêque, Vivien Mathé, 6 Yves Billaud, Aurélie Brodard, Pierre Guibert, Stéphane Jaillet, Olivier Jest, 7 and Mathieu Koehl

\subsection{Introduction}

This chapter details the study of an exceptional and atypical Bronze Age French site of Les Fraux (Dordogne, France), which combines cave art and testimonies of domestic and symbolic activities (Fig. 9.1). The interdisciplinary research conducted on the site since 2007 attempts to untangle the 'interwoven uses' of this cave for later prehistoric communities, during short but regular visitation.

\footnotetext{
A. Burens $(\bowtie) \cdot$ L. Carozza

Environmental Geography Laboratory, CNRS, UMR 5602 GEODE, Toulouse, France e-mail: albane.burens@univ-tlse2.fr; laurent.carozza@univ-tlse2.fr

R. Bourrillon

TRACES-UMR 5608, CREAP, Toulouse, France

\section{S. Petrogani}

UMR 7041 ArScAn, Ethnologie Préhistorique, MAE René Ginouvès, Nanterre, France

P. Grussenmeyer · S. Guillemin · O. Jest · M. Koehl

ICube Laboratory, CNRS, UMR 7357, Photogrammetry and Geomatics Group, INSA

Strasbourg, Strasbourg, France

e-mail: pierre.grussenmeyer@insa-strasbourg.fr; samuel.guillemin@insa-strasbourg.fr; olivier.jest@insa-strasbourg.fr; mathieu.koehl@insa-strasbourg.fr

\section{F. Lévêque · V. Mathé}

UMR 7266 LIENSs, CNRS, Université de La Rochelle, La Rochelle, France

e-mail: fleveque@univ-lr.fr; vmathe@univ-lr.fr

Y. Billaud · S. Jaillet

UMR 5204 EDYTEM, CNRS, Le Bourget du Lac, France

e-mail: yves.billaud@culture.gouv.fr; stephane.jaillet@univ-savoie.fr
}
A. Brodard · P. Guibert
UMR 5060 IRAMAT CRPAA, CNRS, Pessac, France
e-mail: guibert@u-bordeaux3.fr 


\section{Editor's Proof}

A. Burens et al.

Fig. 9.1 The Bronze Age cave of Les Fraux (Saint-Martin-deFressengeas, Dordogne, France): (a, b) Location of Saint-Martin-deFressengeas, Aquitaine (C) Google Maps; A. Burens), (c) Location of the underground network on aerial photograph (orange) (C) Google Map; M. Koehl)

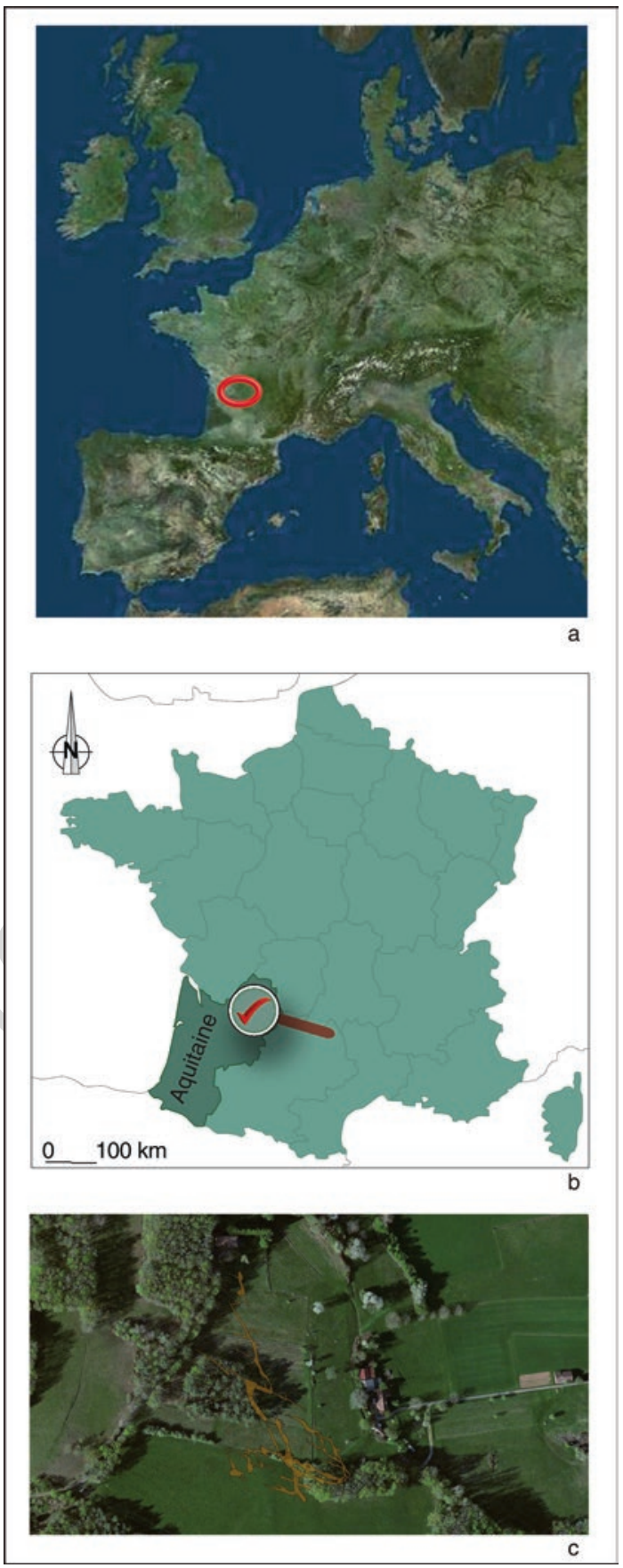


The opportunity to study a cave which temporarily hosted small Bronze Age communities over nearly three centuries allows us to gain a detailed understanding of the nature of activity in relation to the long duration of Palaeolithic occupation that characterises most of the major French painted caves. Indeed, there is no evidence of human activity inside the cave of Les Fraux before the Middle Bronze Age, and none after the Late Bronze Age, when a roof collapse sealed the cave and preserved intact the archaeological remains until 1989: the date of the site's rediscovery. Thus, Bronze Age activity in the cave corresponds to a single period around 1450-950 BC (the maximum duration of human activity inside the cave).

The extraordinary conditions of preservation of the site (due to the collapse of its entrance), and the plurality of human activity of different kinds over a short period of time, force us to take advantage of new technologies, in order to elucidate information unattainable in most French prehistoric painted caves.

By combining chronology, interactions between people and their environment and emerging technologies, our broader objective was to gain a better understanding of the complexity of perceptions of the cave of Les Fraux by local or exogenous prehistoric communities.

One aim was the interpretation of archaeological data within a framework which combined space and time (in which all stages of the research are integrated), from data acquisition, implementation of site monitoring (temperature, $\mathrm{CO}_{2}$ levels, etc.), experimentation and simulation to reconstruction. We employed an integrative and interdisciplinary research approach, based on new technologies able to acquire full $3 \mathrm{D}$ documentation of the entire site (even in inaccessible and non-visible parts) and to process interdisciplinary data according to accurate $3 \mathrm{D}$ models of the cave that constituted the common framework for the various studies and partners involved. The 3D geographic information system of the cave aggregates all types of data produced since 2008, within the same system, including overall 3D recording of structural elements, maps, pictures, analyses, databases, drawings and reports. It allows, for example, for spatial analyses between scientific data and archaeological and geomorphological contexts. By using non-invasive techniques such as laser scanning and photogrammetry, we aimed to preserve the archaeological remains and the integrity of the site, in which all of the material survives in situ, over 9 years of study.

\subsection{The Contribution of the Cave of Les Fraux to Existing Palaeolithic Sites}

The cave of Les Fraux is located in south-west France, in the Périgord-Limousin Regional Natural Park, within the township of Saint-Martin-de-Fressengeas (Fig. 9.1). It consists of a wide underground network (Fig. 9.2), difficult to access, and comprising narrow, damp and sinuous galleries of more than $1 \mathrm{~km}$, formed in a Middle Jurassic geology. Its development is nearly horizontal, following two 


\section{Editor's Proof}

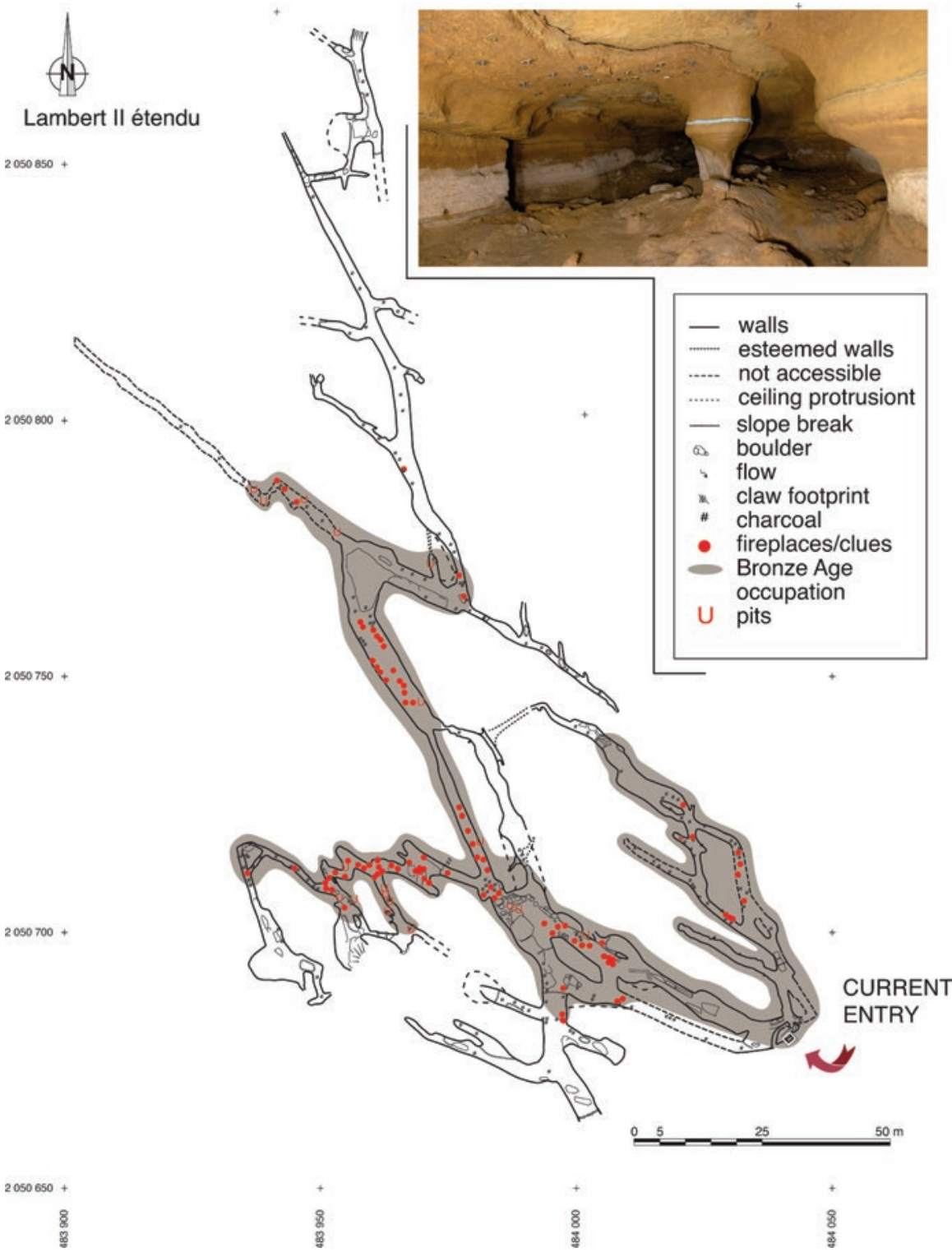

Fig. 9.2 Map of the underground network (Y. Billaud and A. Burens) and view of gallery no. 13. (Photograph: A. Burens)

preferential directions (Burens et al. 2014). The cave comprises two independent parts, simultaneously occupied during the Bronze Age. It is poorly ventilated and does not benefit from natural light: Les Fraux is an entirely dark-zone cave (Faulkner 1988). It might have been chosen for its discrete entrance, which is hardly visible on 
the surface of the landscape. Geomorphological studies indicate that several entrances could have been used since the network's formation, though our reconstruction suggests that the Bronze Age point of entry could have existed near the current one.

The cave is characterised by a succession of phases in which it was alternately accessible and inaccessible. The presence of cave bears demonstrates that the cave was open for a time during the Pleistocene, before its first (undated) obstruction, probably at some point before the Holocene. After a long period of inaccessibility, the cave became accessible once again in the Middle to Late Bronze Age; radiocarbon dating and archaeological investigations suggest that the cave was used from 1450 to 950 BC. At the end of the Bronze Age, the collapse of the cave entrance sealed the cave and preserved intact the archaeological remains until 1989. In short, there is no evidence of human activity in the cave before the Middle Bronze Age, and none after the Late Bronze Age. As a result, the site displays very little evidence of multi-layered deposits (except in one gallery characterised by two different palaeosols); neither does it show evidence for human activity beyond the Middle to Late Bronze Age.

This peculiarity establishes a considerable advantage in our ability to study the relatively short-term perception of the site by ancient communities, in comparison, for example, to Upper Palaeolithic sites, which were generally occupied for longer. For instance, the study of 259 radiocarbon dates from the exceptional Chauvet-Pont d'Arc Cave in Ardèche, France (mainly related to the rock art and human activity), recently highlighted two periods of human activity: one from 37 to 33,500 years ago and the other from 31 to 28,000 years ago (Quiles et al. 2016). This outstanding and unparalleled work has had allowed for a global overview of the site's occupation history and argues in favour of creation of the parietal art before 28,000 years ago. But the temporal sequence of human occupation remains too large to allow for a detailed understanding of the tempo of activity at the cave, in contrast to Les Fraux where the short-term activity helps us to remove any ambiguity in the nature of the various visitations.

The site was discovered in 1989; it was immediately nicknamed the 'Lascaux of the Bronze Age' by French media, owing to its extraordinary archaeological and heritage significance, and was registered with the French Historical Monuments in 1995. According to the French Office of Geological and Mining Research (BRGM), the cave's geology is highly unstable, and it may unfortunately collapse in the coming years. The cave has, therefore, been sealed off to the public, and access is now severely restricted.

The cave of Les Fraux is thought to contain rare examples of Bronze Age cave art in Europe and forms the only protohistorical cave site with evidence for domestic, symbolic and/or votive activities and cave art. When comparing the site with other French Bronze Age caves, there are several similarities. Mostly, however, there are distinct differences, such as the absence of cave art and/or the presence of funerary activity in association with deposits (as is the case, for instance, in Charente, where multiple graves have been found in Bronze Age caves; Gomez 1980). The Bronze Age activity at Les Fraux, which occupies nearly $70 \%$ of the cave (Fig. 9.2), 
left the remains of very well-preserved archaeological deposits, domestic features (such as stairs dug into the clay), torches and postholes, together with no less than 66 hearths and a further 24 traces of hearths. The same galleries included 32 deposits of ceramics and metalwork. The cave contains also many perfectly preserved carvings on the walls and ceiling. Most of the wall art comprises finger-strokes or is otherwise engraved in the clay and comprises linear, schematic and geometric designs (Carozza et al. 2009). All available evidence (typology, radiocarbon dating, etc.) suggests that the cave art and some material deposits should be assigned to the Middle Bronze Age, whilst other deposits date to the Late Bronze Age.

The cave of Les Fraux represents an extraordinary opportunity for study, in all its complexity, of prehistoric cave use (practical versus symbolic) and the significance of this place for prehistoric communities. The short duration of human activity witnessed has also allowed us to create fine-grained chronologies of the various activities taking place.

\subsection{Benefits of New Technologies in Understanding the Complexity of Sites and Their Interwoven Uses}

It was decided that, in pursuit of understanding the complex uses of decorated cave sites, archaeological deposits at the site of Les Fraux would not be destroyed by excavation; their integrity would be maintained for potential future studies. In the course of the study, almost no archaeological material were handled or removed from the site; it was, instead, studied, registered, measured and drawn in situ, without physical contact, or was studied virtually through the use of 3D models (Fig. 9.3). This methodology had a significant impact on how the site was studied and on the conditions under which data were obtained. Working with non-invasive techniques, such as contact-free measurement of ceramic deposits and wall art, was challenging.

The analyses were performed using equipment designed to record the maximum amount of information possible, even in inaccessible or non-visible parts of the cave (narrow galleries, cracks, areas underneath roof collapse, etc.). This 3D protocol corresponded to an attempt from the team to georeference each archaeological and geological dataset from the site and to enforce large-scale spatial analysis, allowing for the full integration of interdisciplinary and multi-scalar data. Furthermore, we aimed to produce 3D models in order to test our archaeological hypotheses and generate accurate visualisation documentation.

We integrated different techniques of data recording based on terrestrial laser scanning, digital photogrammetry and spatial imaging systems (Fig. 9.4), in order to generate geometric and photorealistic 3D models of all structural elements of the cave and of the main archaeological artefacts, from a combination of point clouds and photogrammetric images. Furthermore, our approach integrated different datasets generated at different scales using the various types of 3D recording, including the overall volume of the cave (Fig. 9.5a, b), wall art representations (Fig. 9.5d) and 


\section{Editor's Proof}

9 The Bronze Age Decorated Cave of Les Fraux: Ritual Uses of an Atypical French...
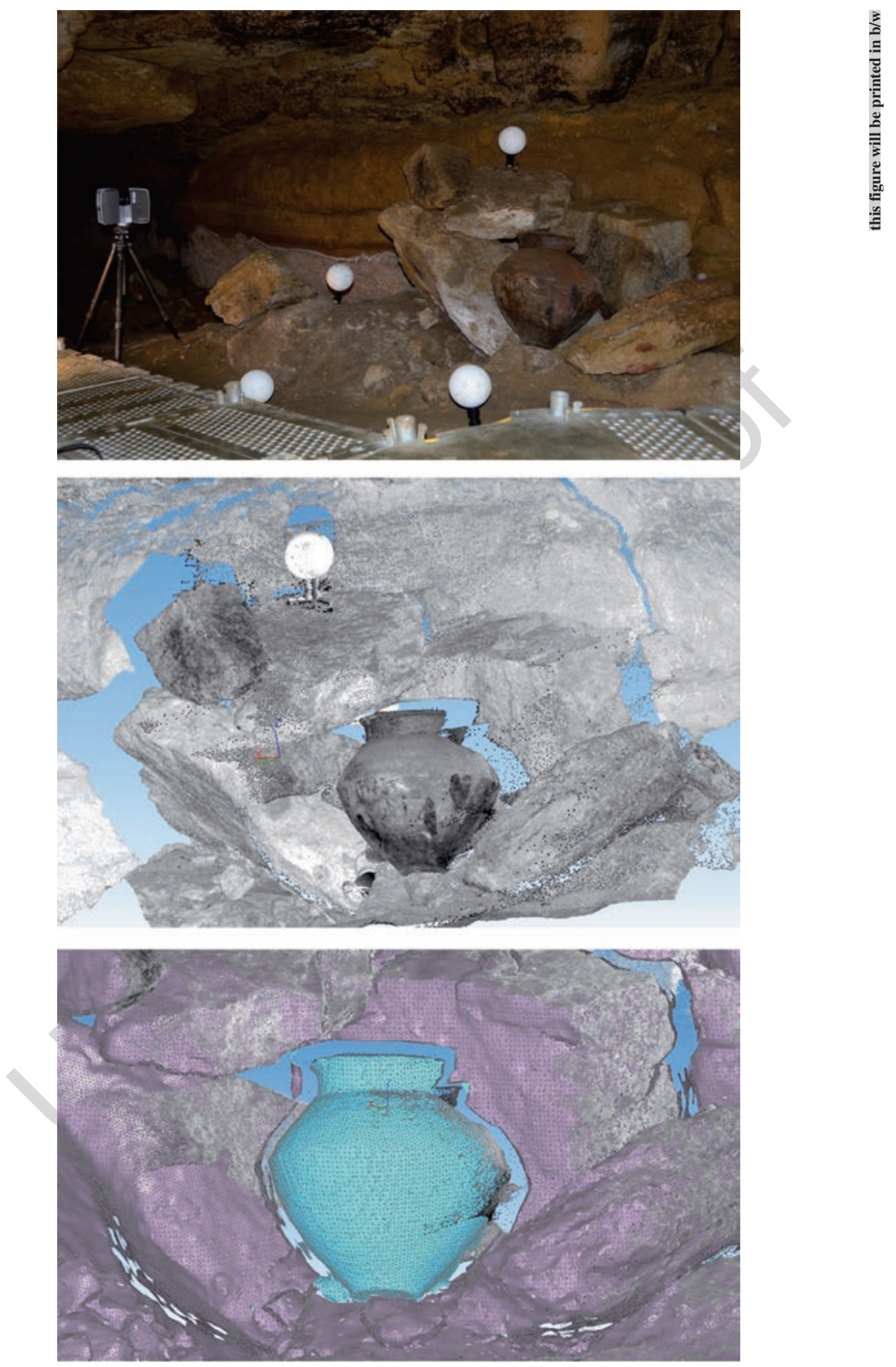

Fig. 9.3 3D recording of a Bronze Age ceramic deposit inside gallery no. 13 (using FARO Focus $3 D$ ): top view of the deposit and of the 3D recording system, middle and bottom visualisation of the deposit as a point cloud (A. Burens, S. Guillemin and P. Grussenmeyer) 


\section{Editor's Proof}
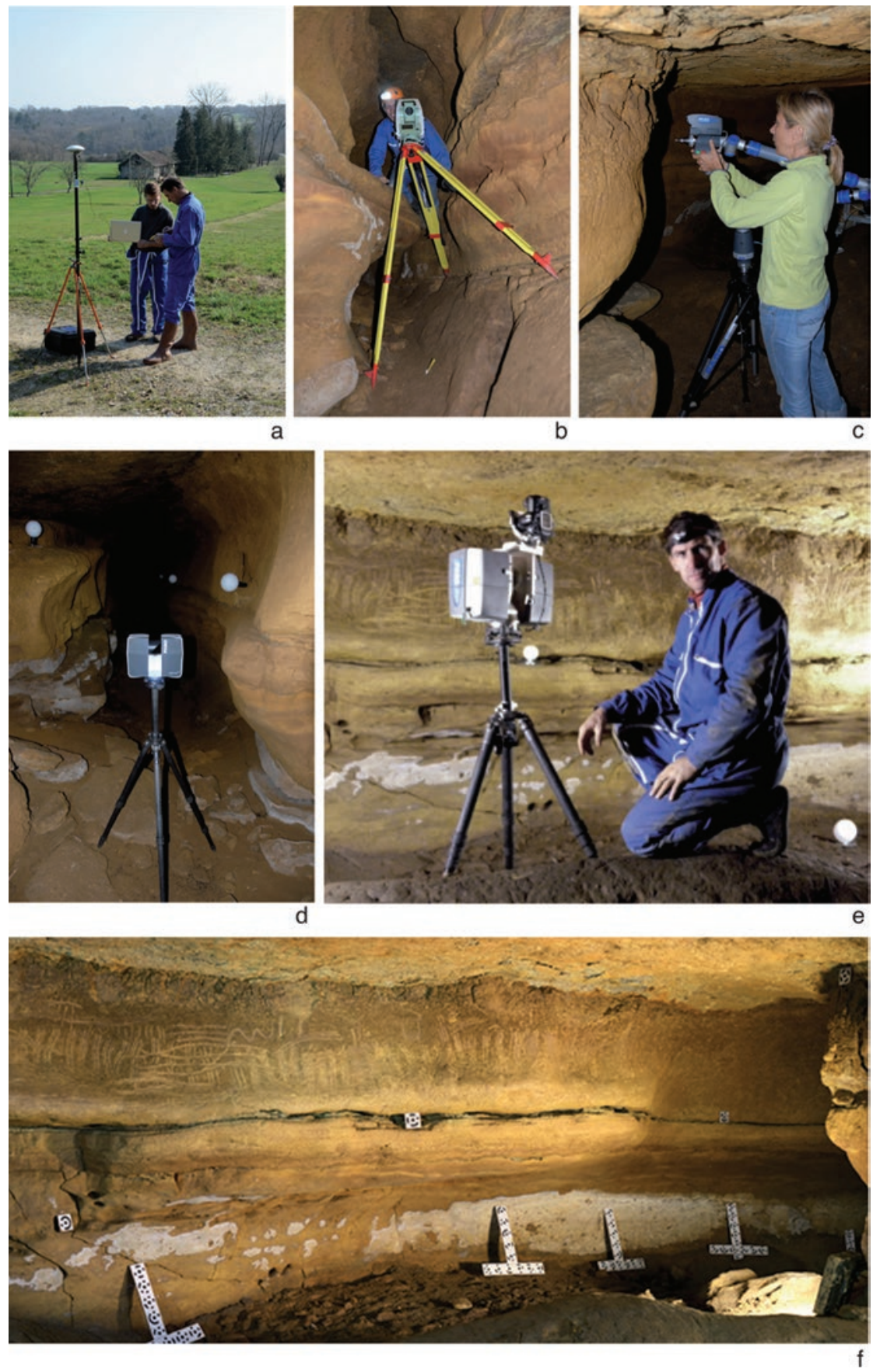

Fig. 9.4 Recording of the total network of galleries by surveying techniques and terrestrial laser scanning (TLS). The cave is linked to the above terrain thanks to surveying techniques (total station underground and GPS measurements in the field): (a) GPS measurements, (b) Surveying techniques by total station, (c, d) TLS, (e) TLS combined with photogrammetry, (f) Photogrammetry. (Photographs: A. Burens) 


\section{Editor's Proof}

9 The Bronze Age Decorated Cave of Les Fraux: Ritual Uses of an Atypical French...
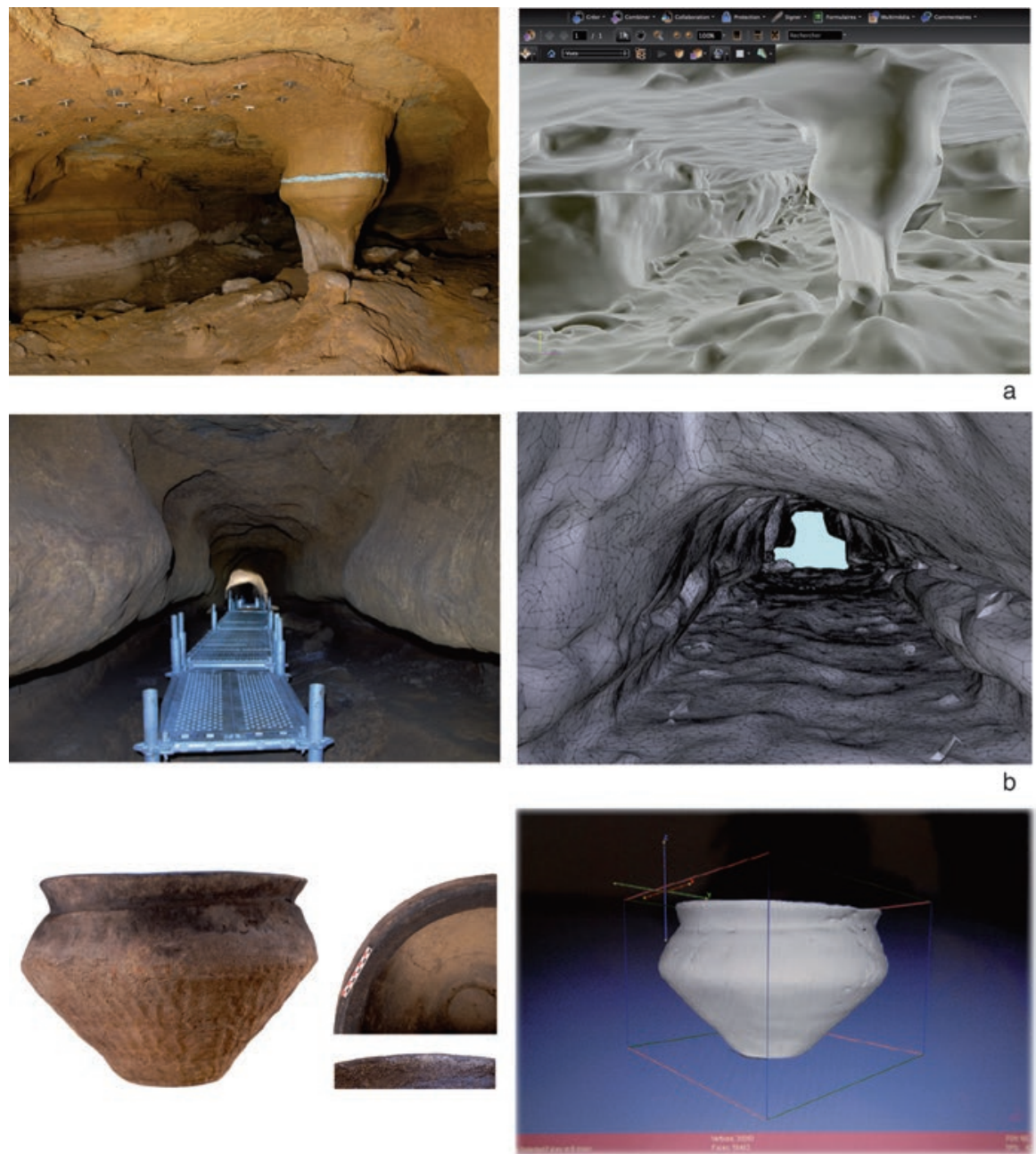

C
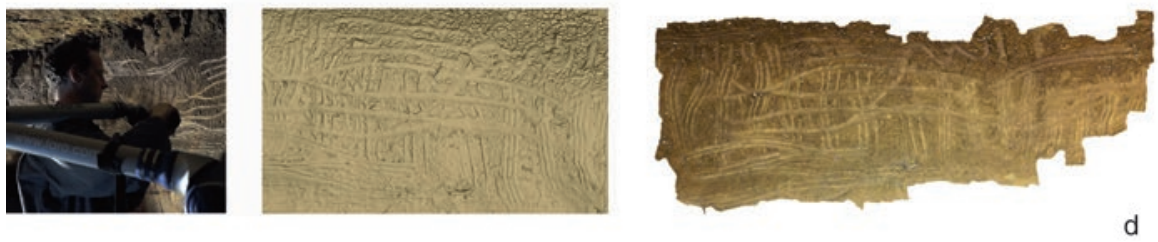

Fig. 9.5 3D recording of archaeological and geological information from the site based on terrestrial laser scanning, digital photogrammetry and spatial imaging system: (a) Image of gallery no. 13 of the cave (left) and its 3D model in PDF 3D format for visualisation in Adobe Reader (right), (b) Image of gallery no. 18 (left) and its 3D model in PDF 3D format (right), (c) 3D recording of a Bronze Age vessel from the cave, coated with the charred remains of animal fat, (d) 3D recording of the main decorated panel from gallery no. 13 (S. Guillemin, P. Grussenmeyer and A. Burens) 
archaeological deposits (Fig. 9.5c), and demonstrating that it was in fact possible to combine, in the same depiction system, several different sources of information.

These data not only included drawings (such as sections and elevations) but also photorealistic perspectives from different viewpoints and visual 3D models. We also implemented various other interdisciplinary studies, including different modelling approaches, magnetic field mapping, palaeoenvironmental reconstructions and a simulation of the cave's thermal dynamics. In addition, we tested innovative and experimental approaches which combined photogrammetry and terrestrial laser scanning, including photorealistic rendering of the cave art. The documentation and recording work contributed to accurate indexing and georeferencing of the entire set of surveys, images, structural models and relief drawings acquired in the different parts of the cave.

The following sections provides a technical overview of some of the basic methods used in the study, in order to reconstruct and model the cave and to help us understand the character of the various human activities which took place within it.

\subsubsection{Overall 3D Recording of Structural Elements}

Overall recording of the cave by terrestrial laser scanning (TLS) was our first goal, since it allowed for georeferencing of any type of object, image or measurement and accurate indexing of the data between the various researchers involved in the project. The study began with consolidation of the topography and the creation of a polygonal network inside the cave with a total station. This network was connected to the landscape outside the cave by several geodetic points, measured using differential Global Navigation Satellite System techniques. The first TLS campaigns were undertaken using a FARO Photon 120 Scanner, which was well-adapted for the central underground passage. Since 2012, data acquisition has been undertaken using a FARO Focus $3 D$ Scanner. The expected accuracy of both scanners is about $2-5 \mathrm{~mm}$ at $25 \mathrm{~m}$. The scanner was moved along the galleries, and an overlapping area between two stations was routinely provided. More than $600 \mathrm{~m}$ of galleries have been recorded so far (Fig. 9.6), requiring more than 130 stations and 30 days in the cave.

Handling data from multiple stations required resampling of the individual point clouds, which were then imported and merged into a single point cloud. The need to facilitate the exchange and dissemination of data within the team led us to export the global 3D model of the cave, resampled at 1 point/cm, in 3D PDF format. This format allowed for the retention of measuring functions and toolkits (distances, sections, etc.), as well as visualisation options (such as wireframe, shaded, solid, vertices).

We also recorded ceramic and metalwork deposits within the galleries (Figs. 9.3 and 9.5c). When the 3D model was transformed into 3D PDF, it was then possible to draw, measure and define the section and typology of every ceramic artefact, without the need for any contact with the deposit (though this approach was not possible for completely inaccessible deposits, such as pottery almost entirely hidden within and between rocks). 


\section{Editor's Proof}

9 The Bronze Age Decorated Cave of Les Fraux: Ritual Uses of an Atypical French...
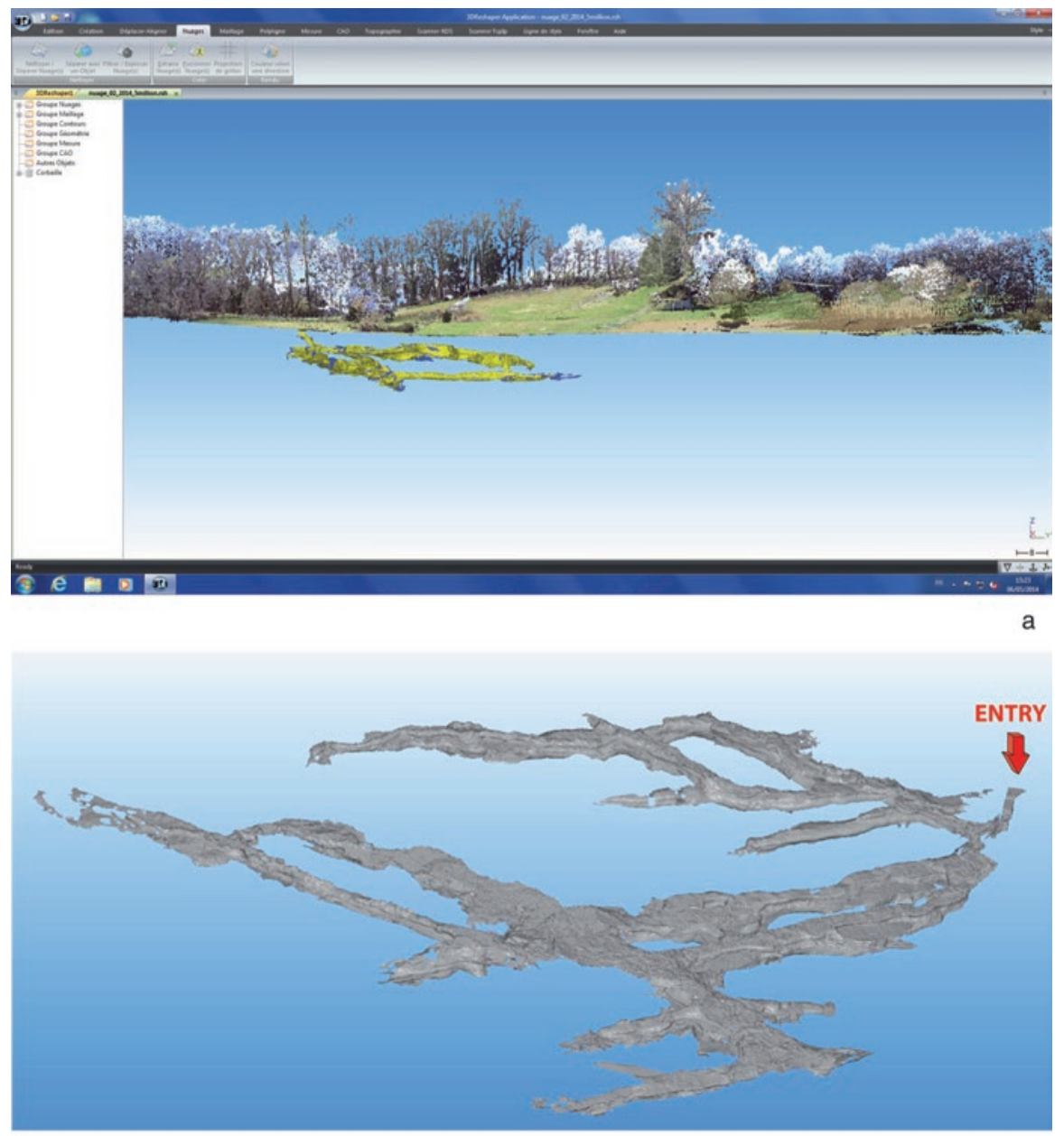

Fig. 9.6 Global 3D models of the underground network of the cave; data recorded in the French Geodetic Reference System (Lambert 2) (P. Grussenmeyer, S. Guillemin and A. Burens)

\subsubsection{Photorealistic Rendering}

In archaeological caves, studies of wall art require the processing of high-definition images with greater accuracy than is usually necessary for the total volume of the underground network. A common solution is the correlation of high-resolution digital photographs of specific panels with 3D volumetric models of the cave (Grussenmeyer et al. 2012). The aim of the experimental work developed in Les Fraux since 2008 was to find an interface between the 3D imaging methods and the 


\section{Editor's Proof}

176

A. Burens et al.

reconciled the subtleties of traditional drawing with the rigorous precision and swiftness of 3D survey (Fig. 9.7). We managed to negotiate, for the first time in an archaeological cave, access to the latest generation of a FARO ScanArm V3 (19,200 points/s and $0.035 \mathrm{~mm}$ accuracy). The exceptional quality of the resulting point cloud is due to the accuracy of the FARO fusion arm and ensuring that the laser V3 head remained only a few centimetres from the object during the time-consuming recording process. This new equipment, providing submillimetre resolution, has enabled the team to succeed in mapping high-definition images onto a very accurate 3D model, in order to obtain photorealistic rendering of the decorated panels by combining photogrammetry and TLS. Orthophotos from the 3D models were used (after digital image enhancement processing) to support vectorisation of the decorated panels and produce an alternative to traditional and time-consuming drawings by creating an accurate, georeferenced image. This technique provided better recording of superimposed archaeological depictions, in order to gain a better understanding of their relative chronology. The recording of cave art using orthophotos, based on 3D models, will prove very useful for archaeologists.

We were also able to carry out experimental work on identifying the various techniques and tools used to create the decorated panels, by comparing 3D models of several in situ panels with their experimental counterparts (Fig. 9.8). The latter were made in soft clay materials placed in vertical frames. Finger-strokes were hand-made, whilst engravings were made using a wide range of tools on the surface
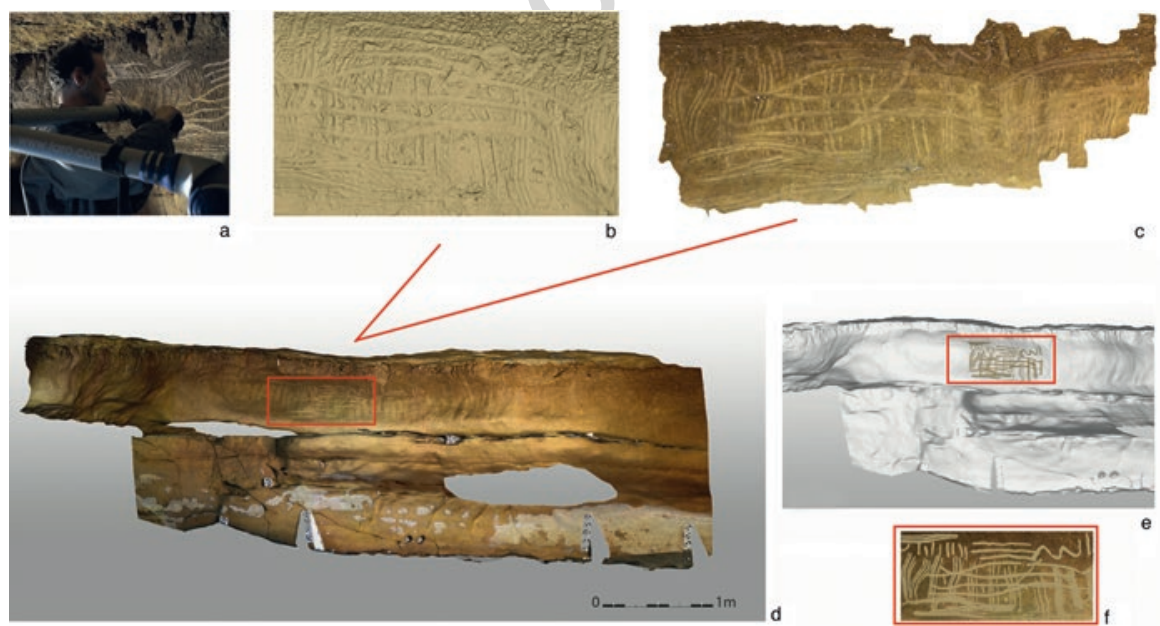

Fig. 9.7 3D recording of Bronze Age finger-strokes in the clay wall of the main panel from gallery no. 13 of the cave: (a) Recording test with the FARO ScanArm, (b) View of the high-density point cloud recording using the FARO ScanArm, (c) Digital surface of a selected piece of the panel, (d) Textured 3D model, (e) Projection of drawn finger-strokes on the 3D model, (f) Detail of the digital drawing from the orthophoto extracted from the 3D model (S. Guillemin, P. Grussenmeyer and A. Burens) 


\section{Editor's Proof}

9 The Bronze Age Decorated Cave of Les Fraux: Ritual Uses of an Atypical French...
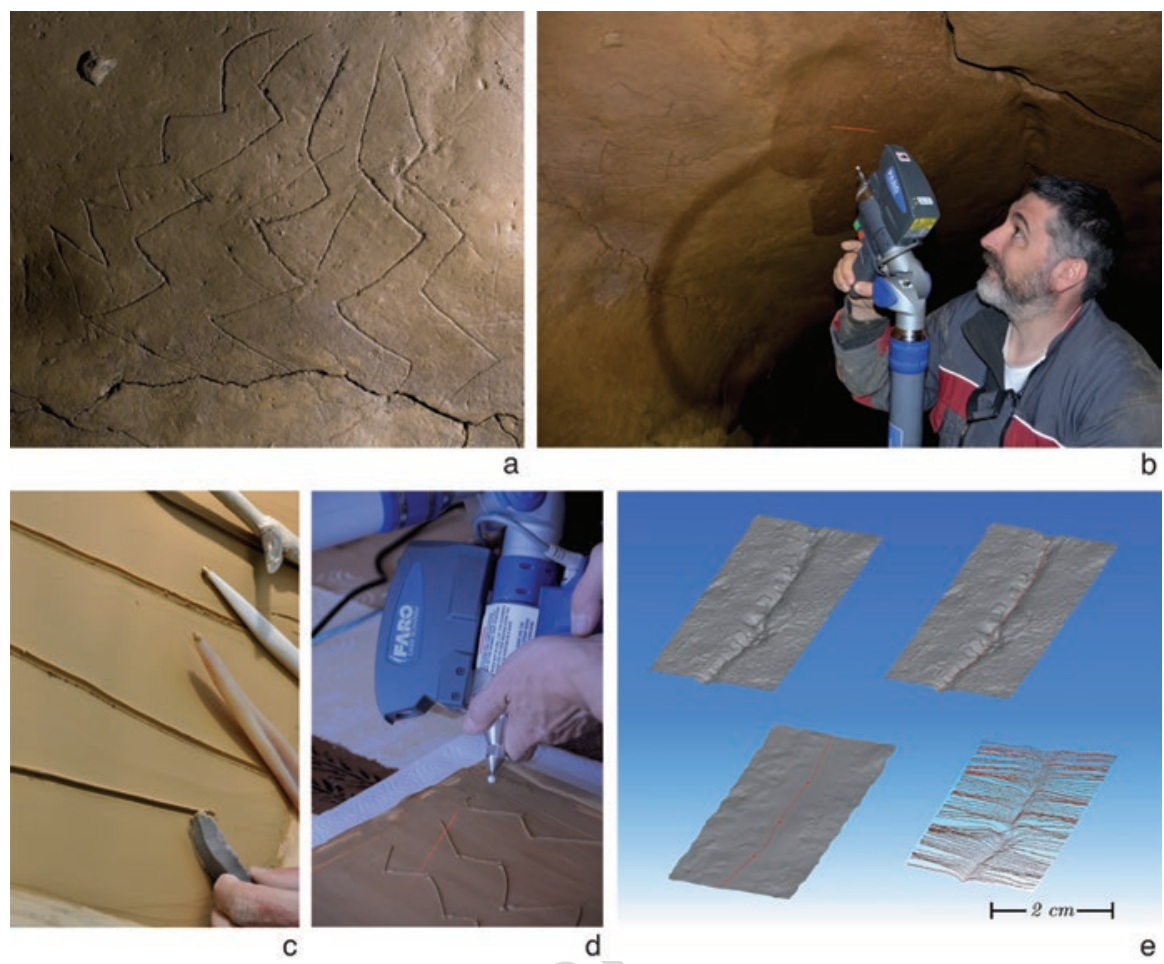

Fig. 9.8 3D recording of a decorated panel from gallery no. 10 and its experimental duplicate with the FARO ScanArm: (a) View of the decorated panel, (b) 3D recording of the decorated panel by TLS with the FARO ScanArm, (c) Preparation of experimental duplicates with different tools, (d) Scanning the experimental duplicate used as reference, (e) View of the section of the finest carvings from the decorated panel (A. Burens, S. Guillemin and P. Grussenmeyer)

of the clay: flint, bone, bronze and copper spikes, dry wood, freshly cut branches, fingertips, etc. Drawings were created in conditions close to those observed on site (e.g. moisture content of clay, position of drawing inside the cave, etc.). The aim was to attempt to differentiate between the various techniques used to create the motifs, such as finger-strokes, engraving using tools or etching. The flexibility of the head of the ScanArm used for this work allowed for recording of the base of even the thinnest engravings, including oblique ones, both on the in situ panels and their experimental counterparts. Indeed, the laser can be oriented effortlessly in all directions. After, we compared sections through the 3D archaeological motifs with the 3D experimental duplicates in order to assess the morphology and types of tools used. By using this approach, we were able to propose the probable use of wooden and metal tools for the execution of engravings. 


\section{Editor's Proof}

\subsubsection{The Les Fraux 3D Geographic Information System}

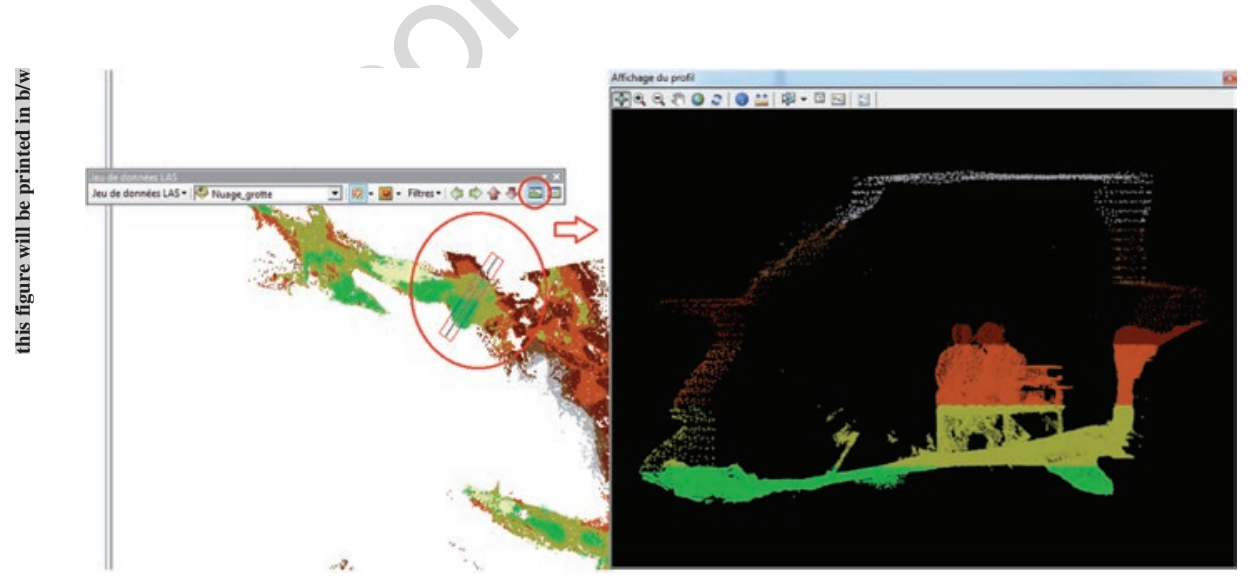

Fig. 9.9 Left screenshot from the cave of Les Fraux 3D geographic information system (gallery

Fig. 9.9 Left screenshot from the cave of Les Fraux 3D geographic information system (gallery
no. 28), right handling of 3D point clouds in ArcMap 10.2 viewing window and the creation of sections (O. Jest, M. Koehl, A. Burens)

The Les Fraux 3D GIS was designed to store, manipulate, manage, present and share the huge amount of 2D and 3D spatial and geographical data produced and georeferenced by the total station and laser scanning (Fig. 9.9). This system allowed us to create interactive queries, interrogate spatial information and edit data in maps whilst also taking into account the location and nature of archaeological artefacts and geomorphological contexts. A 3D approach is crucial in the context of underground networks. Thus, chose a system able to manage 3D point clouds (ArcMap 10.2) and temporalities. Unlike traditional relational databases, this GIS processes the spatial dimension of multi-scalar and heterogeneous data of various different disciplines. The conceptual data model thus expresses relationships between multidisciplinary information. Very large datasets, including images, maps, analyses, reports in JPEG and PDF formats and associated objects and features, have been integrated within this GIS.

According to this system, we are able to produce 2.5D thematic maps-in which the coordinates of a point $[\mathrm{x}, \mathrm{y}]$ are associated with only one altitude $[\mathrm{z}]$ - to simulate $3 \mathrm{D}$ movement within the galleries, to manage archives (images, analysis, etc.) and to create automated dynamic mapping of atmospheric measurements. Some tools deal with the spatial analysis of artefacts, hearths, deposits and decorated panels, in relation to other entities (e.g. the close association between the location of decorated panels and symbolic deposits). Overall 3D recording of the cave structural elements constitutes the basic element of the GIS. 3D data were resampled before being integrated in the GIS. The georeferenced point clouds allowed for the $3 \mathrm{D}$ visualisation of the cave and of the semantic data linked to artefacts and geological objects recorded on the site. Data were either quantitative or qualitative. Semantic data were located according to the point clouds (i.e. the structural elements of 
the cave). They were processed in a table before being integrated into the GIS. Vector data (2D maps) were exported in DWG format for georeferencing and integration into the GIS. Raster data were used as the background of the GIS and also required coordinates.

The GIS included, for example, all information related to the hearths (morphology, location, spatial context, presumed function, analysis, radiocarbon date, etc.). Preliminary analyses suggest that spatial correlations exist between hearths and other elements which structured space, such as votive deposits, cave art or domestic debris. Thus, the GIS constitutes an important tool for analysing the location of the hearths within their immediate environment.

Now that the georeferenced data gathering period is complete, our goal is to create a reconstruction and simulation of the various past activities which took place in the cave, using the 3D models of the cave and the GIS. The integration of temporality in 3D numerical simulation is an important challenge for our understanding of the development of the underground network, from the modern day to various hypothetical past states, particularly in terms of palaeoclimate. Furthermore, this tool already provides a way for us to compare 3D models of different archaeological cave systems using spatial analysis, in order to deepen our knowledge of human interaction with these environments.

In this regard, archaeologists and surveyors from the team have committed themselves to a new project based on archaeological and ethnographic analogy: studying a historical underground network, temporarily occupied by a small population and documented by direct testimony (living witnesses, pictures, written accounts, historical archives, etc.), akin to Cyril Marcigny's study of the Norman quarries of Caen (Carpentier et al. 2016). Our collective goal is to study, under the same conditions as those implemented at Les Fraux, the quarry of 'Saingt', Fleury, Normandy. The latter was occupied by the local population in June and July 1944 (through the allied troops' bombing raids during the so-called Normandy landings). It has been digitised in 3D according to the same techniques to those implemented at Les Fraux, in order to produce 3D models of the site and a 3D GIS. Preliminary results allow us to observe a wide range of similarities in the spatial distribution of artefacts (the remains of meals) and living spaces between these two underground networks. The comparison of characteristics between one site and the other encourages us to reconsider some of our interpretations of Les Fraux, notably that some activity in the cave is more domestic in character than might otherwise have been expected. It is important to note, however, that ethnographic and ethnohistorical evidence cannot always be used as a direct parallel for archaeological interpretations. As TolanSmith and Bonsall (1997, p. 217-218) warn us, 'the dimension of human behavior... is notoriously difficult to appreciate in periods before the emergence of documented history and recorded ethnographic observation', and 'the distinction between economic and ritual behaviour may be partly false as it arises from the application of a twentieth century rationalist perspective which may not be entirely appropriate in other contexts'. 
295

296

297

298

299

300

301

302

303

304

305

306

307

308

309

310

311

312

313

314

315

316

317

318

319

320

321

322

323

324

325

326

327

328

329

330

331

332

333

334

335

336

337

\subsection{The Visible and the Unseen: The Issue of Hearths}

Hearths, which are widely considered as structuring elements, especially in caves, provide important information about the nature of space occupation. Sixty-six domestic hearths (Figs. 9.2 and 9.10) have been recorded in the cave of Les Fraux, together with a large amount of combustion products, across the entirety of the area which saw activity during the Bronze Age (this is to say, nearly $70 \%$ of the network). Some structures are partially washed away or buried by sand from the decay of sandstone blocks or flood events.

We have recorded 41 fireplaces built directly on the ground surface, 10 hearths not attributable to a specific type because of their poor state of preservation, 7 fire pits (both in natural and anthropogenic features), 5 instances of the indirect evidence of hearths (such as traces of reddening on the cave ceiling or walls and isolated heat-effected sandstone blocks) and 3 hearths made from clay extracted from inside the cave. One of these latter features is represented by a semi-elliptical shape, a ridge of clay and a pattern made with a thumb; the only one protohistorical parallel for this is in Ouessant, Finistère (Le Bihan and Villard 2010).

The exceptional preservation of most of these structures has allowed us to collect quantitative and qualitative data relating to their function. We have established a classification based on morphology, location in relation to their immediate surroundings, dimension, typology (see Beeching and Gasco 1989; Gasco 2003) and the materials used in their construction. Most of the hearths are characterised by their small dimensions ( $<0.35 \mathrm{~m}$ in length) and quadrangular shape; they are located on slopes, in passageways, near to walls or atop ridges. In some cases, delimitation devices have been observed (e.g. sandstone blocks or imprints left by stones). Three hearths were built on top of large blocks. They seem to have been used for lighting and heating. Larger hearths and fire pits $(0.35-0.65 \mathrm{~m}$ in length), characterised by higher fire intensity $\left(>300{ }^{\circ} \mathrm{C}\right.$ ), are located in narrow galleries (with low ceilings) and more open spaces (rooms). Some of them are close to material deposits and domestic debris; their uses seem more variable. Flat hearths might have been used for baking.

All of the information related to fires has been registered in the $3 \mathrm{D}$ database (including morphology, typology, location, archaeozoological remains, photographs, description of geological alterations and combustion remains, taphonomy, radiocarbon date, charcoal analysis, fire intensity, etc.). A novel approach to understanding the intensity of these fires has already been published, based on a combination of archaeological observation and analyses of hearth sediments (i.e. thermoluminescent properties of the sedimentary quartz; see Brodard et al. 2012) and relevant proxies obtained from experimental structures (Brodard et al. 2016). This study is thought to allow for the evaluation of fire intensity of hearths (temperature/time/energy) and to contribute to our understanding of their role and their impact on the ground, walls and atmosphere of the cave.

In addition, we wanted to find a way to map potential hidden, displaced or ruined structures. This was another innovative approach, managed by two of the team (F. L. and V. M.), and was particularly interesting in terms of 3D modelling, in 


\section{Editor's Proof}

9 The Bronze Age Decorated Cave of Les Fraux: Ritual Uses of an Atypical French...
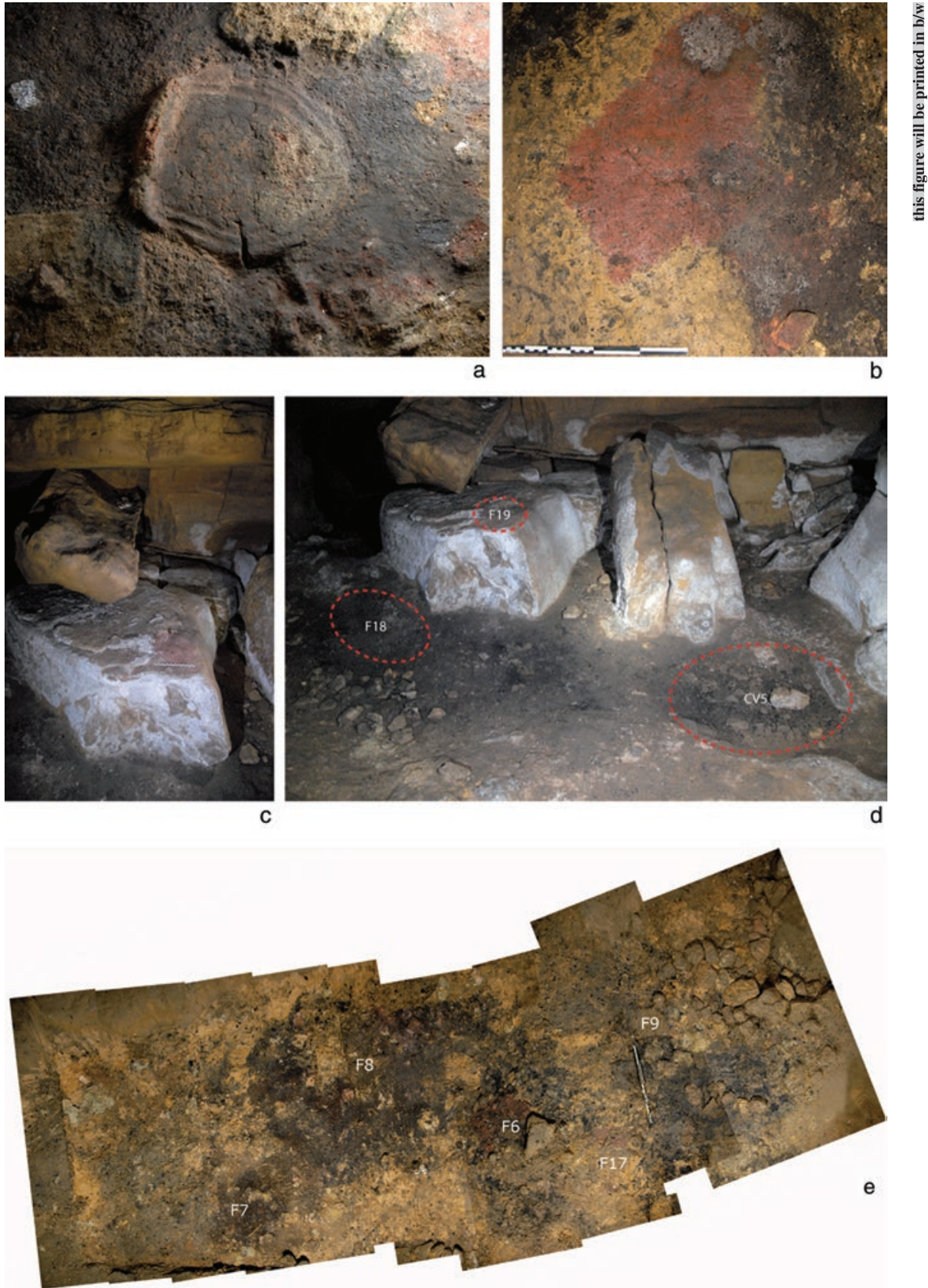

Fig. 9.10 Overview of some hearths in the cave: (a) Gallery no. 13, (b) Gallery no. 18, (c, d) Gallery no. 29, (e) Bronze Age palaeosol from the gallery no. 13 and its five hearths (F3, F5, F7, F9 and F17) (photographs: A. Burens) 


\section{Editor's Proof}

establishing significant progress in our methodological framework. On outdoor archaeological sites, cartography of local distortions of the earth's magnetic field (e.g. generated by the thermal impact on soil or sediment) allows researchers to locate ancient hearths (visible, or not) or other structures. For the first time, François Lévêque and colleagues successfully adapted this technique of magnetic survey to the underground network at Les Fraux. The complex topographic configuration of the underground galleries required full 3D data acquisition (instead of the usual 2D acquisition), together with higher resolution data capture. All rocks interact more or less with the earth's magnetic field, depending on their nature and their thermal history. The interpretation of local variation in the magnetic field required us to clearly identify the source of an anomaly (i.e. the highest and lowest values of intensity of the local magnetic field). In order to distinguish topographic effects from the impacts of fire, both magnetic and topographic information were combined in the same $3 \mathrm{D}$ model of the cave.

The 3D cartography of local distortions of the earth's magnetic field in relation to Les Fraux was useful in helping to complete the inventory of ancient hearths, both visible and invisible. Measurements of the magnetic field were recorded in the cave using a dual-sensor magnetometer coupled to a $360^{\circ}$ prism reflector (Fig. 9.11). Geolocation of measurements was ensured by tracking the $360^{\circ}$ prism with a total station. This magnetic field mapping project succeeded in combining, in the same depiction system, several sources of magnetic, topographic and archaeological information (Fig. 9.12). Due to this innovative 3D approach, we were able to map unseen hearths within the cave and to differentiate in situ structures from displaced hearths (Burens et al. 2014). This new method is now applied to other French painted caves, for example, the caves of Cussac, Dordogne and Chauvet Vallon-Pont-d'Arc, Ardèche.

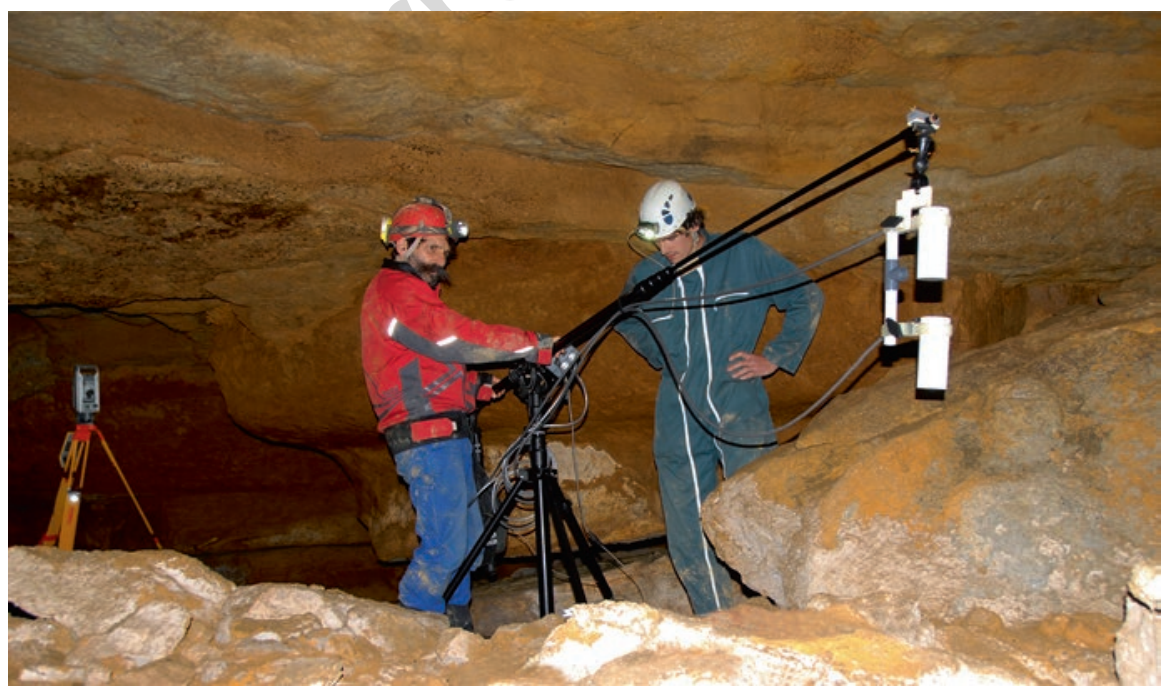

Fig. 9.11 View of the 3D magnetic prospection device inside gallery no. 40. (Photograph: A. Burens) 


\section{Editor's Proof}

9 The Bronze Age Decorated Cave of Les Fraux: Ritual Uses of an Atypical French...
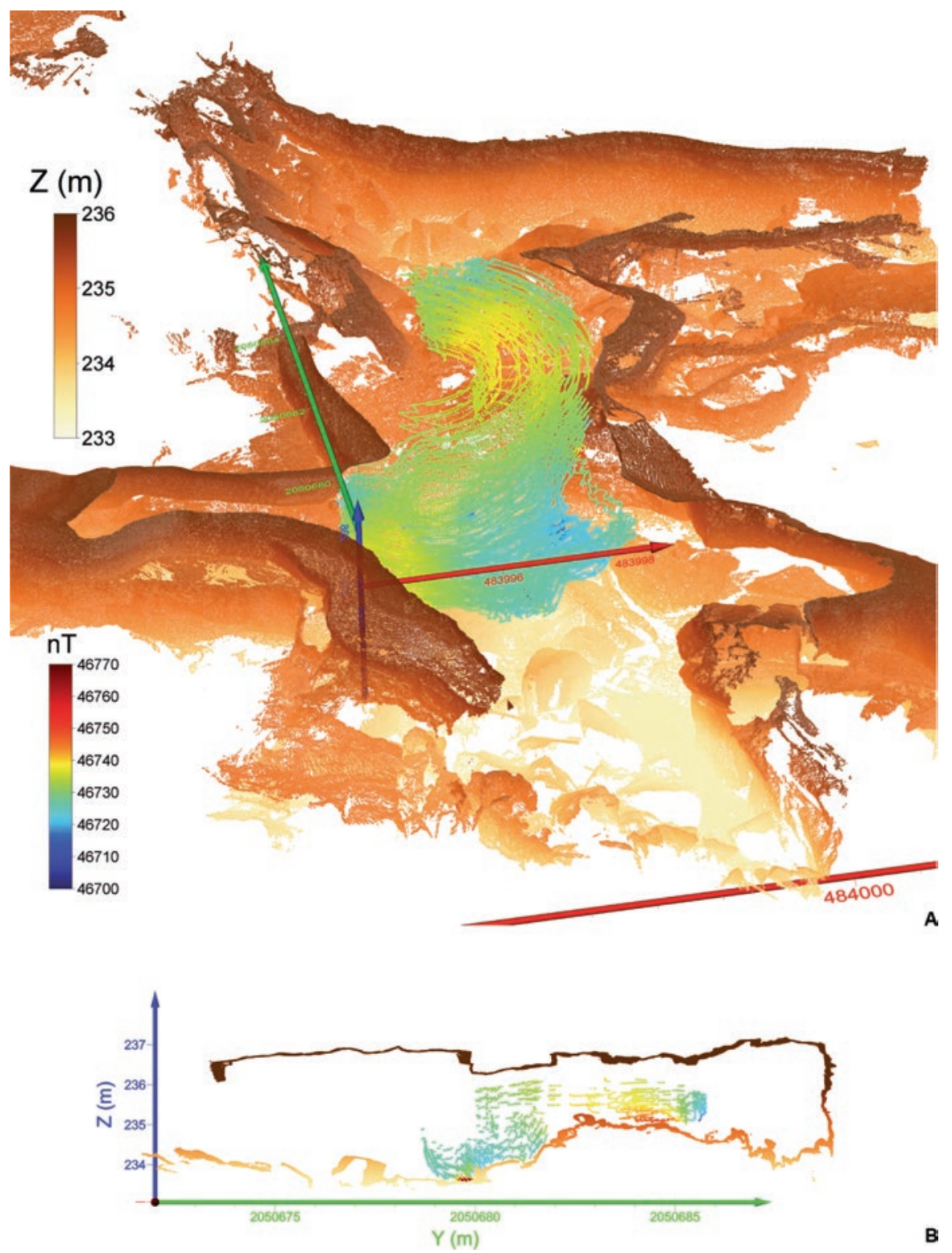

B

Fig. 9.12 Protocol of 3D magnetic prospection in the cave of Les Fraux: (a) Device comprising a telescopic pole fixed on a tripod allows for good control of the space covered by the sensors (white cylinders); geolocalisation of the measurements are obtained by a tracking method thanks to a total station, (b) Gallery no. 40: 3D mapping of the magnetic field (georeferenced in Lambert 2). The magnetic survey is created with a telescopic boom pole fixed on a tripod. Both sensors are superimposed and hanging at the end of the pole. The point clouds of both intensity of the magnetic field and wall surface are shown on image (a) (the top of the cave is truncated). Thanks to a second magnetometer, the diurnal variation of the local earth magnetic field is corrected. Image (b) displays a vertical section, $20 \mathrm{~cm}$ in thickness (F. Lévêque) 
363

364

365

366

367

368

369

370

371

372

373

374

375

376

377

378

379

380

381

382

383

384

385

386

387

388

389

390

391

392

393

394

395

396

397

398

399

400

401

402

403

404

405

\subsection{Types of Space Use and the Meaning of Cave Art}

As mentioned above, nearly $70 \%$ of the cave of Les Fraux displays significant evidence for Bronze Age human activity (Fig. 9.2). That said, we have also found traces of lesser activity throughout the whole cave (isolated charcoal, imprints on the walls, etc.), which probably indicates a willingness to recognise and utilise the entire underground network. Our results show that a whole range of evidence for different types of activities (such as hearths, fire pits, faunal remains and wood, ceramic sherds, postholes, votive deposits, stairs dug into the clay, toolmarks on the walls, torches, etc.) were present in a wide range of galleries, even those which were narrow, had low ceilings or were located a long way from the entrance. It must be understood that no remains have been recovered from around the cave entrance, owing to the burial of archaeological deposits by sediment that have flooded in from outside (Fig. 9.13). Nevertheless, it appears that people occupied all parts of the cave, from the entrance to remote parts of the interior, with the exception of inaccessible or inhospitable galleries (which were too damp, too poorly ventilated, rich in carbon dioxide, difficult to access, temporarily flooded or affected by subsidence, etc.). Multiple lines of evidence indicate that at least some of the archaeological deposits are associated with domestic activities (Carozza et al. 2009); conceivably, the cave may have been used as a temporary shelter during a period of climatic change (e.g. the $3.2 \mathrm{ky}$ BP event). But regarding the spatial location of the cave art, spread over 75 cumulative linear metres (the network extends over more than $1 \mathrm{~km}$ ), our understanding of the cave's use over time needs to be reconsidered.

The cave contains a vast amount of cave art (Figs. 9.13, 9.14, 9.15 and 9.16), featuring a wide range of schematic and geometric drawings widely dominated by parallel traces and finger-strokes (>80\%) (Petrognani et al. 2014). This preponderance gives the impression of a low variability of patterns, made in a repetitive way, using predominantly one technique (fingers: $>75 \%$ ).

The drawings have preserved their integrity (Figs. 9.14, 9.15 and 9.16), whilst blocking of the cave and the effective sealing of this archaeological context suggest a high degree of authenticity. The spatial distribution of art does not represent continuous development, even if some small sections present an almost uninterrupted continuous sequence of patterns; it is random in its composition (Fig. 9.14). Drawings have been recorded in 13 different galleries; only 4 display hundreds or thousands of marks. Around 1500 graphical entities and 73 panels contain nonfigurative motifs. The right network of passages (looking in from the entrance) has delivered a remarkable concentration of 39 decorated panels and 90 groups of motifs. The left network is characterised by a less dense concentration of drawings, with 26 decorated panels and 54 groups of motifs, but it contains the largest and most elaborate panel of cave art (in gallery no. 13). Motifs have been formed using four different techniques (Fig. 9.17). By far the most common is finger-strokes, with more than $70 \%$ rendered using this technique. Two, three or four fingers were deliberately pressed several times onto the moist clay of the wall and were moved vertically, horizontally or obliquely, forming sequential unexplained patterns. The 


\section{Editor's Proof}

9 The Bronze Age Decorated Cave of Les Fraux: Ritual Uses of an Atypical French...

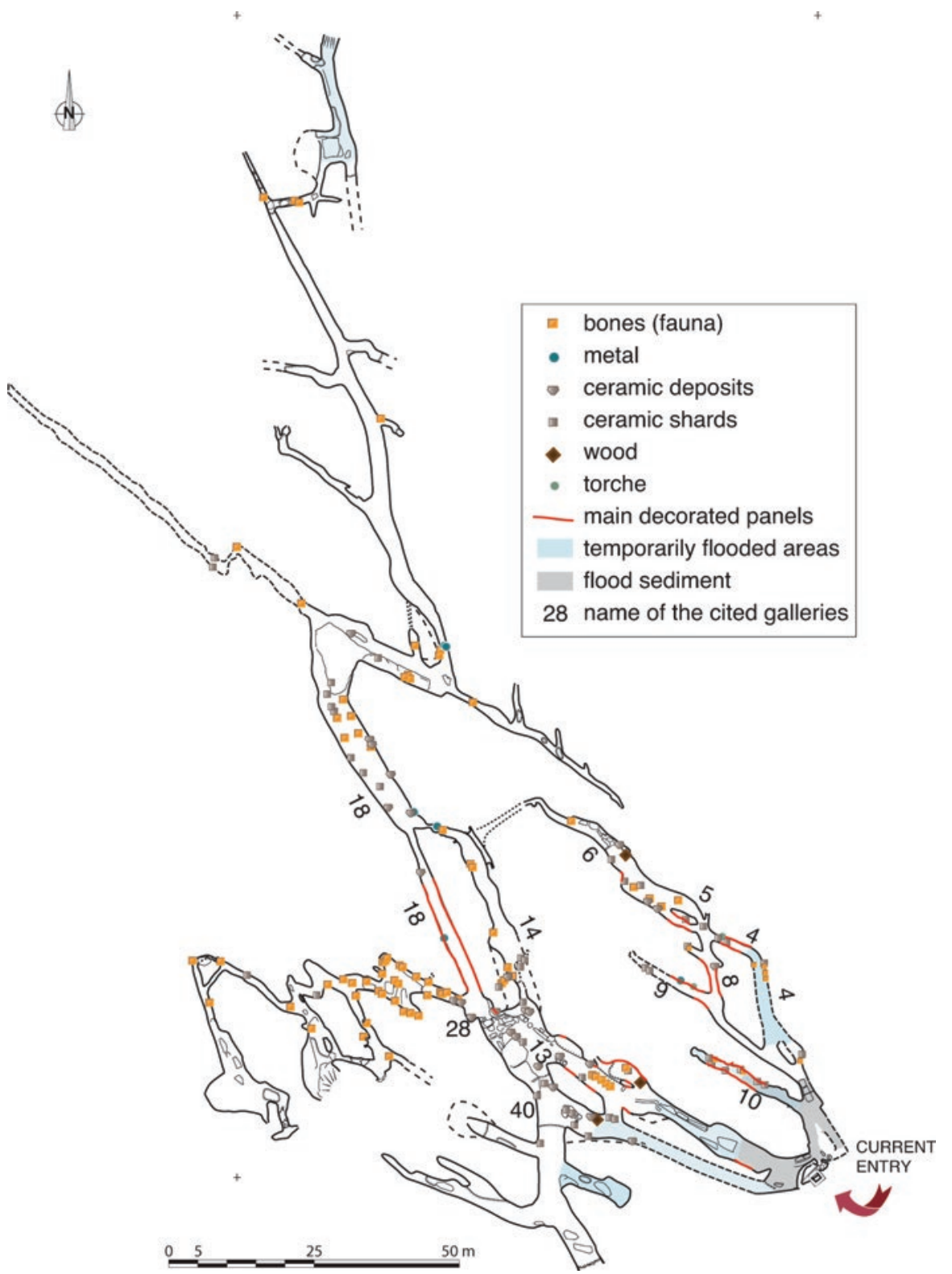

Fig. 9.13 Map of the underground network displaying the location of cave art and other material (Y. Billaud and A. Burens) 


\section{Editor's Proof}

186

A. Burens et al.

है
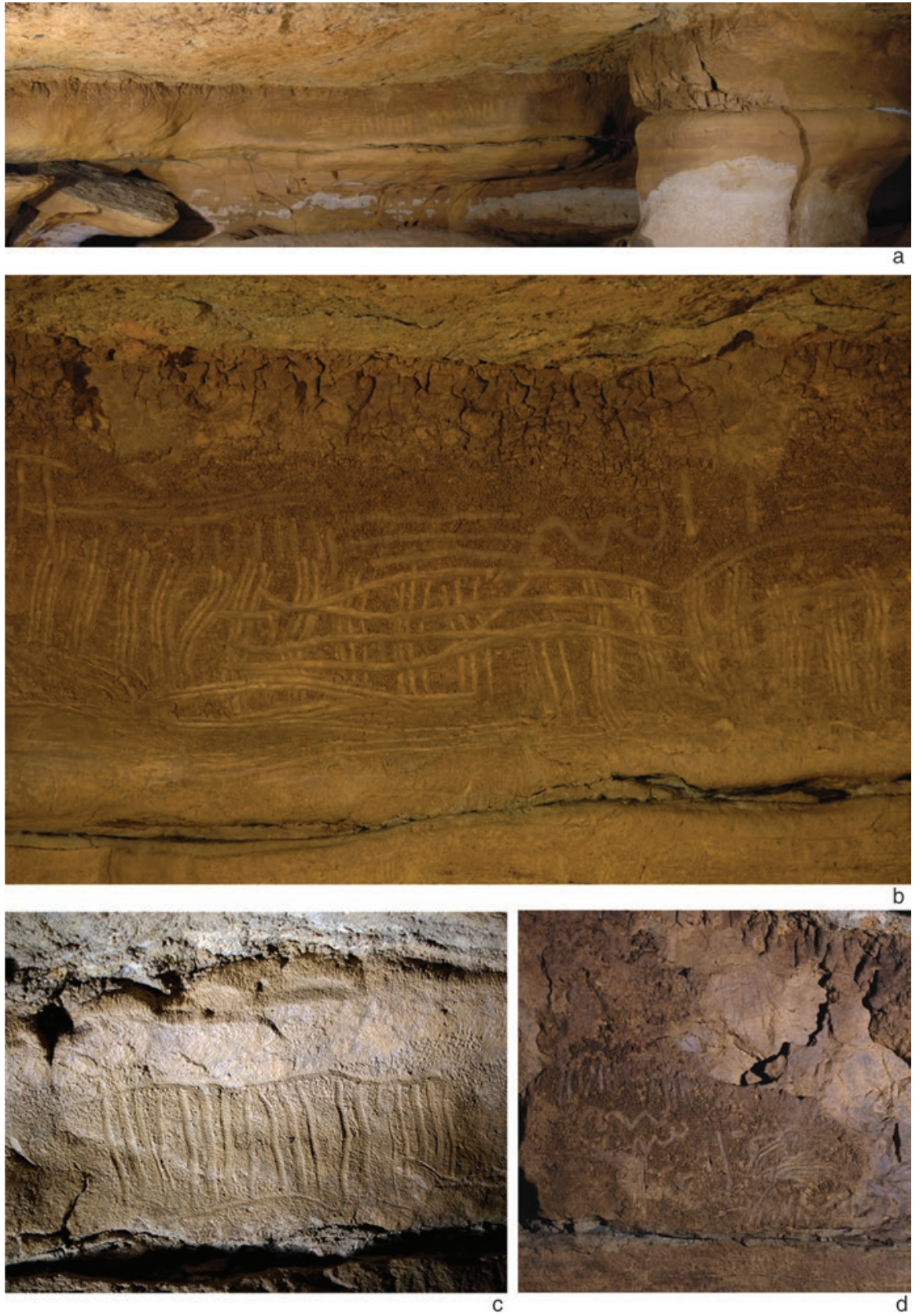

Fig. 9.14 A select range of decorated panels from gallery no. 13. (Photographs: A. Burens and R. Bourrillon) 


\section{Editor's Proof}

9 The Bronze Age Decorated Cave of Les Fraux: Ritual Uses of an Atypical French...
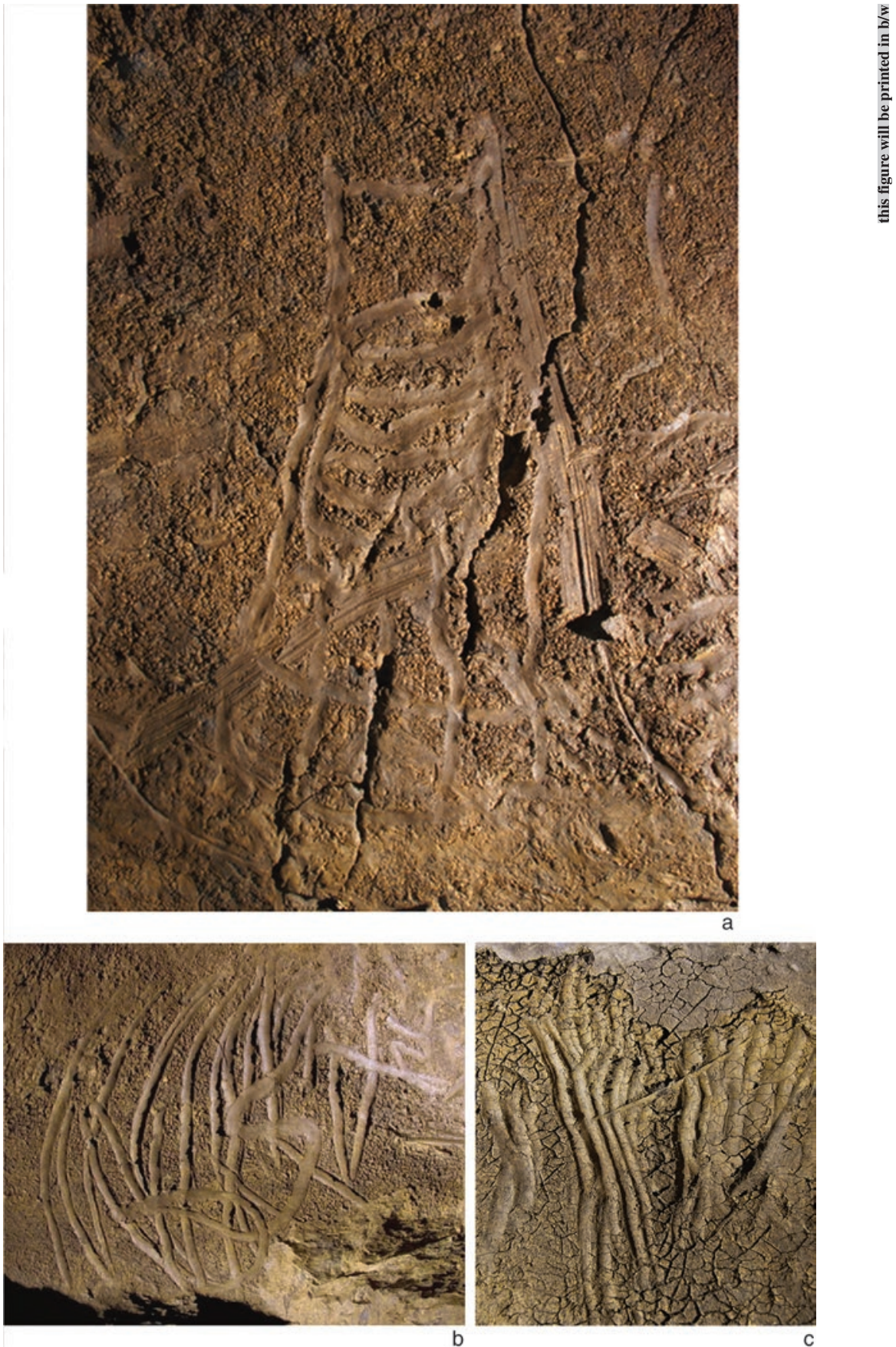

Fig. 9.15 A select range of decorated panels from the cave: (a, c) Gallery no. 13, (b) Gallery no. 28. (Photographs: A. Burens and R. Bourrillon) 


\section{Editor's Proof}

188

A. Burens et al.

है

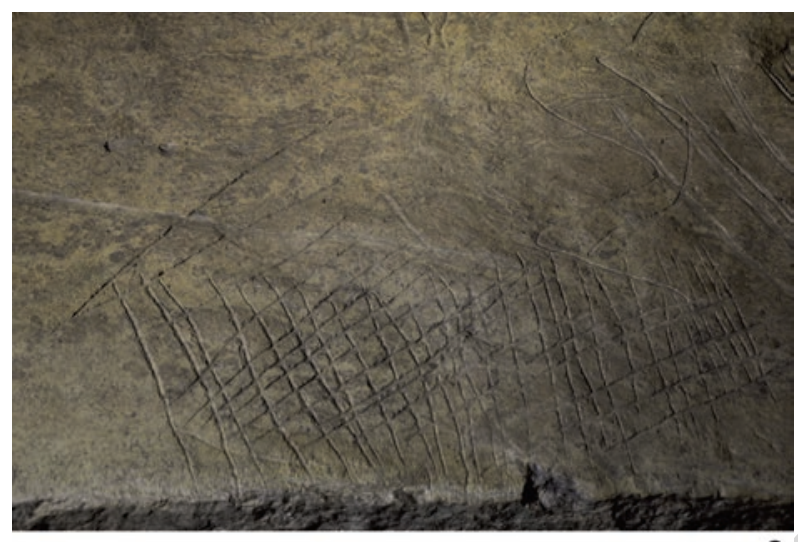

a

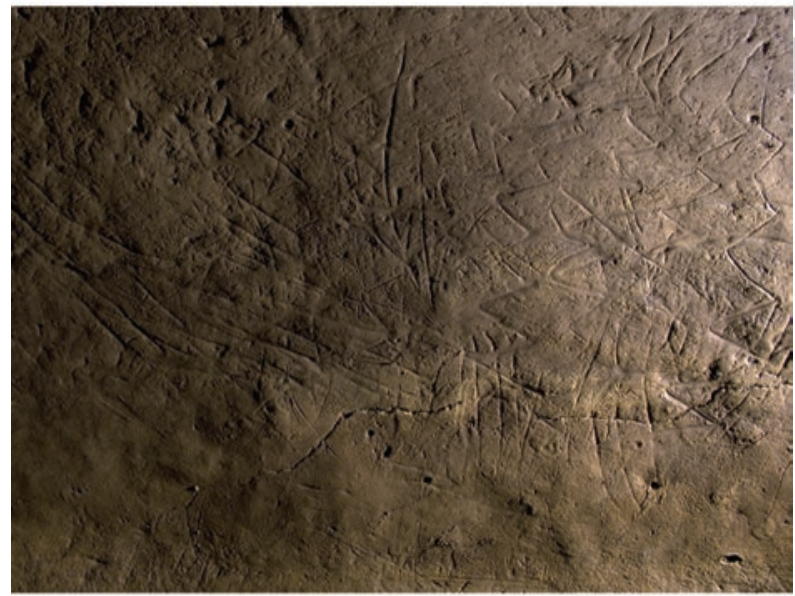

b

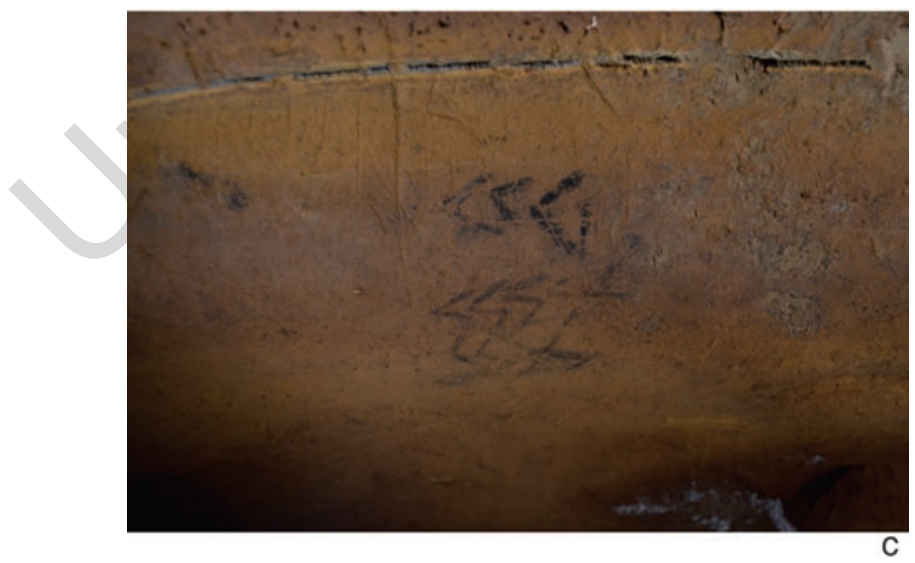

Fig. 9.16 A select range of decorated panels from the cave: (a) Gallery no. 6, (b) Gallery no. 10, (c) Gallery no. 9. (Photographs: A. Burens and R. Bourrillon) 


\section{Editor's Proof}

9 The Bronze Age Decorated Cave of Les Fraux: Ritual Uses of an Atypical French...

Fig. 9.17 Les Fraux cave art: (a) Technical characteristics, (b) Presentation of the main patterns (A. Burens, R. Bourrillon and S. Petrognani)
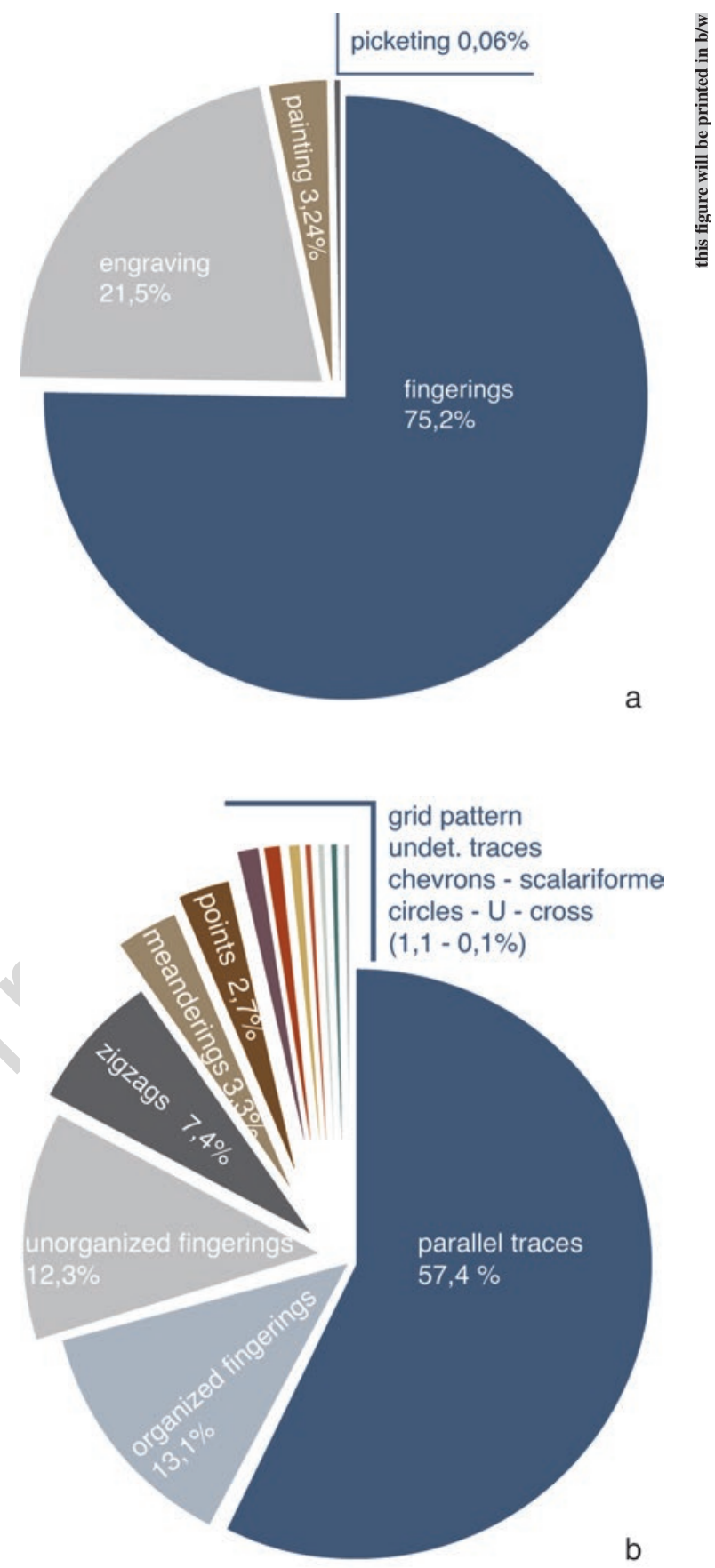
406

407

408

409

410

411

412

413

414

415

416

417

418

419

420

421

422

423

424

425

426

427

428

429

430

431

432

433

434

435

436

437

438

439

440

441

442

443

444

445

446

447

448

449

second most common technique is engraving (with more than $20 \%$ of motifs rendered in this way): patterns were engraved by using metal and wooden tools pressed into the soft clay surface of the rock (Burens-Carozza et al. 2011). Finally are painting and pecking techniques. Only two techniques have been discovered in the left part of the cave network, which contains the densest concentration of motifs rendered by finger-strokes, together with some engravings. In contrast, all four techniques have been used in the right part of the cave network. Two are exclusively represented in this area: the painting and picking technique. Engraving is also predominant in this part of the cave, but finger-strokes are less common. Motifs are organised into 13 different patterns, reflecting a rich symbolic system (Fig. 9.17). They comprise a relative wide repertoire, including parallel lines (which predominate), organised and unorganised finger-strokes, zig-zags, meanders, points, grid patterns, undetermined motifs, chevrons, scalariforms, circles, U shapes, crosses and so on.

For Marcel Otte, the Mediterranean Bronze Age is characterised by an extreme degree of symbolism, but often excluding human representations (except in the south-east of France and in the mountains; Otte et al. 2002, p. 193). Variations can of course be explained by various cultural influences, such as those from the Atlantic associated with the 'Tumulus Culture' in Aquitaine and the north of France, or the emergence of the Duffaits Group in Middle Bronze Age in Perigord (Carozza et al. 2009; Gomez de Soto 1995; Otte et al. 2002). In karstic regions, however, caves are rarely decorated; the cave of Les Fraux constitutes an exception.

Even though direct dating of the cave art of Les Fraux remains somewhat speculative and is based on the maximum duration of the human activity on the site (from 1450 to $950 \mathrm{BC}$ according to relative chronology and radiocarbon dates), it seems that we should assign at least some of the wall art to the Middle Bronze Age. Indeed, radiocarbon dating has been undertaken on a charcoal sample from inside one of the motifs on a large decorated panel in gallery no. 18 and returned a date of 14101190 BC (at 98\%) and 1380-1210 BC (at 68\%) (Lyon SacA 15,773: $3035 \pm 35$ BP).

The cave art only features in a small part of the underground cave network. Its spatial distribution, however, shows a good correlation between art, hearths, the remains of domestic activities and votive deposits. In seven galleries, cave art is closely associated with votive deposits, whilst in the same areas decorated panels have been found near to pot sherds and other archaeological remains (animal bone, metalwork, etc.). In the four most decorated galleries (nos. 8, 13, 18, 28), panels are closely associated with contemporaneous hearths, perhaps in order to provide light. On the contrary, however, in six other galleries (nos. 4, 5, 6, 9, 10, 14), no visible hearths have been found in close proximity to cave art. Here we observe a clear disconnect that cannot be explained purely to problems of taphonomy.

Residential and ritual activity is rarely witnessed simultaneously in the same cave. Work in progress, especially in gaining additional radiocarbon dates and refining our relative chronology, could eventually create a more detailed understanding of these patterns of activity and whether they were indeed contemporary or sequential. 
From a different perspective, research on reverberation sounds in caves suggests links between prehistoric paintings and the acoustic properties of the places in which they were created (e.g. Bahn 1997, p. 37; Clottes 2003, p. 21; Lewis-Williams 2002, p. 225; Reznikoff and Dauvois 1988; Sieveking 1997, p. 29). In France, studies conducted in Palaeolithic caves (e.g. Grotte du Portel, Niaux, Fontanet) have shown-by measuring the intensity and duration of sounds and changing resonances in relation to the point of emission - a correlation between the location of paintings and the acoustic properties of that peculiar location within the cave. Reznikoff and colleagues (1988) have found that major points of resonance within caves tend to correspond to the location of paintings. Furthermore, the location of some paintings seems to be exclusively explained by the acoustic properties of that specific place. It might be suggested that prehistoric communities developed close associations between the ritual uses of the voice (or other sound sources, such as musical instruments) and cave paintings. In the cave of Les Fraux, work in progress has revealed that the main decorated panel of the cave is located in the most important room within the network (gallery no. 13), in that it offers the best resonance of any part of the cave. Furthermore, some unusual resonances have been observed between two different galleries, not in direct contact with one another, and in two different branches of the cave system. At these peculiar locations, deposits of pottery and metalwork have been found, in some cases associated with engraved motifs and finger-strokes. Of course, more concrete evidence is needed, and this preliminary work is based on qualitative observations, but it seems that, in the cave of Les Fraux, the acoustic properties of the cave might also have been important in the Bronze Age for artistic or ritual expression.

It is worth at this stage remembering that we have no idea of the meaning of the cave depictions. The significance of geometric patterns remains unknown. In Spain, some figures (e.g. zig-zags, meanders) which are associated with figures, such as deer, could depict water or thunderstorms (Hameau 2009). The grid patterns and scalariforms are, however, dissimilar from Alpine rock art, such as those discovered in the Val Camonica (Anati 2009). At the cave of Les Fraux, interpretations remain largely speculative and range from utilitarian functions, artistic expression and space appropriation to a counting or measuring system. Alternatively, do the signs represent the property or the presence of a group, or were they made consciously or under altered states of consciousness, induced by a sensory deprivation linked to silent, isolation and a totally dark environment (Barnatt and Edmonds 2002, p. 125; Lewis-Williams 2002, p. 214)? We have explored different and alternative avenues of research, including modern fetishist practices, such as those performed in Burkina Faso and Mali, and which involve heaps of pot sherds and finger-strokes in ground surface, in order to ward off evil (Pataux 2010), evidence very similar to that observed at Les Fraux. The motifs might also be associated with story-telling, in a similar way to the mnemonic Rongorongo tablets used by people who recite oral traditions on Pascua Island. The difficulty arises when the culture and its traditions are of great antiquity. The originality of the iconography of the Les Fraux cave art sets it apart from traditional European protohistorical rock art. There are few parallels for this non-figurative art, and often the archaeological contexts in which it is 
495

496

497

498

499

500

501

502

503

found are undated. Locally, Rouffignac Cave displays some finger-rendered motifs that could possibly be assigned to the Bronze Age (Barrière 1974, 1975). Some parallels can also be found in Spain, but the activity represented there is much older (e.g. Ojo Guareña Cave, tune de la Varaime; Gómez-Barrera 1999) or the parallels are less obvious (e.g. Cueva Mayor). Furthermore, Bronze Age rock art, megalithic art and cave art shares a wide range of geometric designs with other protohistorical periods, whilst the indiscriminate comparison of artefacts across time and space leads to inappropriate analogies (Wylie 1985).

\subsection{From Domestic Use to Votive Practice}

Through the course of this chapter, we have discussed the rich archaeological character of the cave of Les Fraux. Some of the activities represented seem to relate to the domestic sphere, whilst others relate to ritual practices. In relation to Neolithic caves in Ireland, Marion Dowd (2008, p. 305) notes that 'Understanding the use of caves... has to begin with a careful evaluation of the material available and its context'. For William Walker (1995), objects used during rituals are made sacred and must be disposed of in respectful ways. 'Many of us report finding broken objects in caves that may be the result of ritual activities occurring at the site, so broken votive offerings may be an imperative of ritual practice' (Moyes 2012, p. 8). If this is the case, how do we set ritual remains apart from domestic objects? Despite renewed interest in this issue, it remains difficult to objectively define the notion of 'deposit'.

Inside the cave of Les Fraux, the galleries include 32 deposits, the majority of which comprise ceramics and more rarely metalwork (3), faunal remains (5) or speleothems (1) (not to mention pebbles deliberately deposited on raised areas of calcite) (Figs. 9.18 and 9.19). Unlike other protohistorical caves in France characterised by rich deposits - especially those excavated in Charente-Maritime by José Gomez de Soto (1980) - the cave of Les Fraux has not yielded any human remains, and thus no association with the funeral sphere can be objectively confirmed. Half of the deposits are located in eight galleries which also include cave art, where they are located under or close to decorated panels. But in seven galleries, deposits are located some distance away from wall art panels.

Some of the deposits are organised in a highly visible way (at the junction of galleries, on the top of stone blocks, etc.); others are intentionally hidden (under boulders, inside crevices, etc.). Meanwhile, metal artefacts (necklaces, small bronze rings, pins, etc.) and faunal deposits are often spatially distinct from ceramic deposits (which include a large range of storage, cooking and fine ceramic vessels). Deposits sometimes comprise complete vessels, but most often they are broken; most bear traces of use, with some coated with the charred remains of animal fat (ongoing work by Arnaud Mazuy and Martine Regert, UMR7264). The requirement to leave all archaeological material in situ, and working with non-invasive techniques, forced the team to study the ceramic deposits using contact-free 


\section{Editor's Proof}

9 The Bronze Age Decorated Cave of Les Fraux: Ritual Uses of an Atypical French...
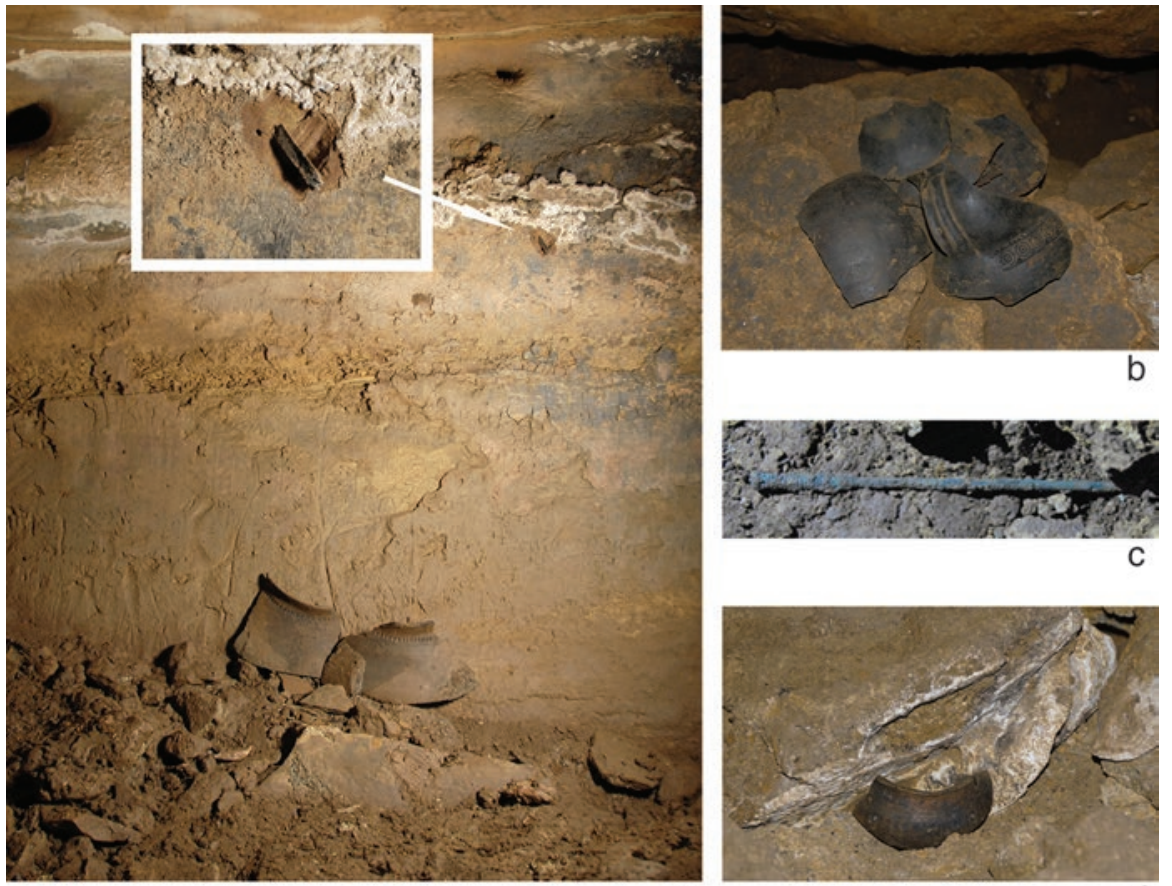

a
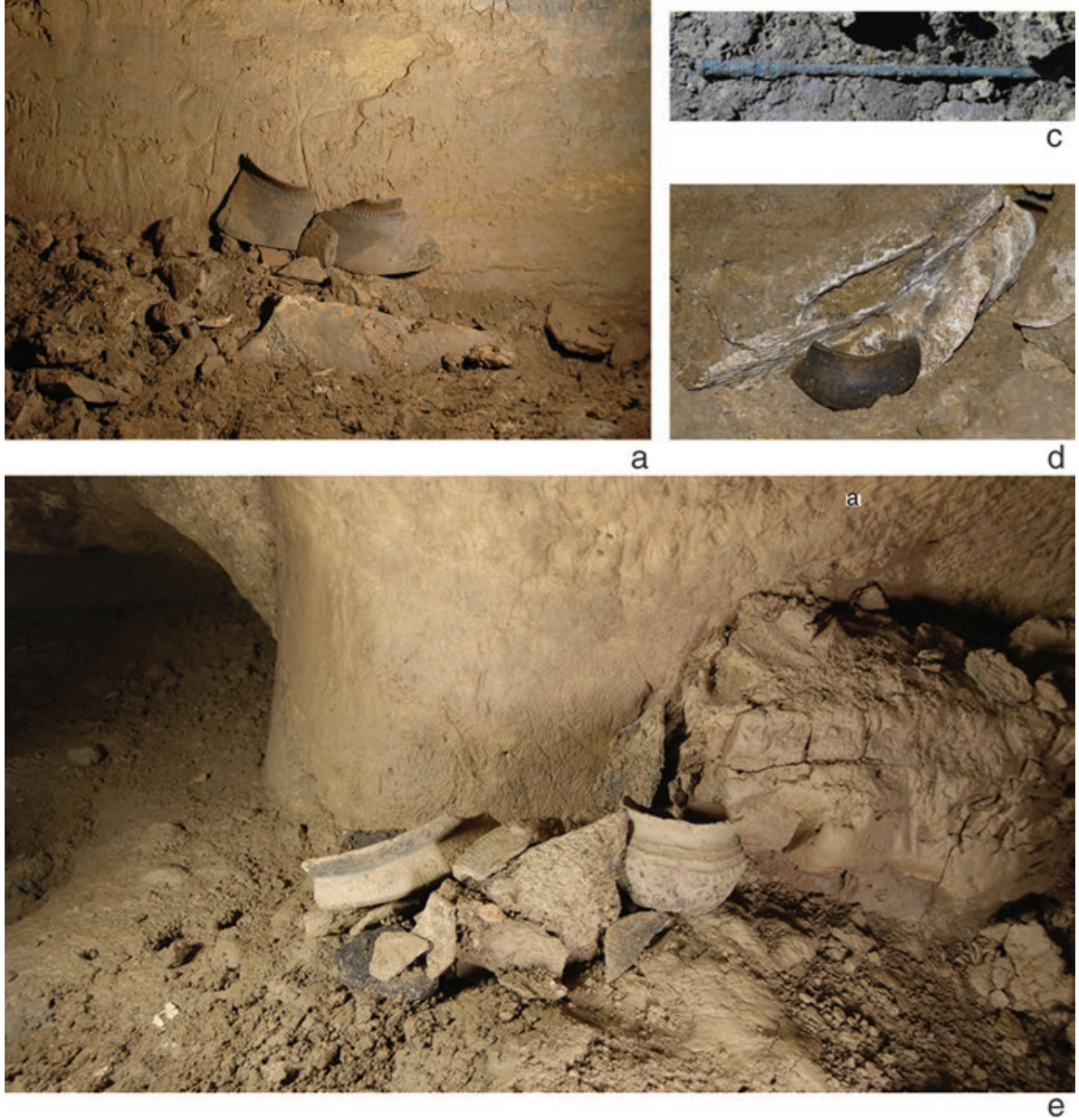

d

Fig. 9.18 A select range of deposits in the cave: (a) Gallery no. 6, (b, d) Gallery no. 18, (c) Gallery no. 12, (e) Gallery no. 8. (Photographs: A. Burens) 


\section{Editor's Proof}

194

A. Burens et al.

है
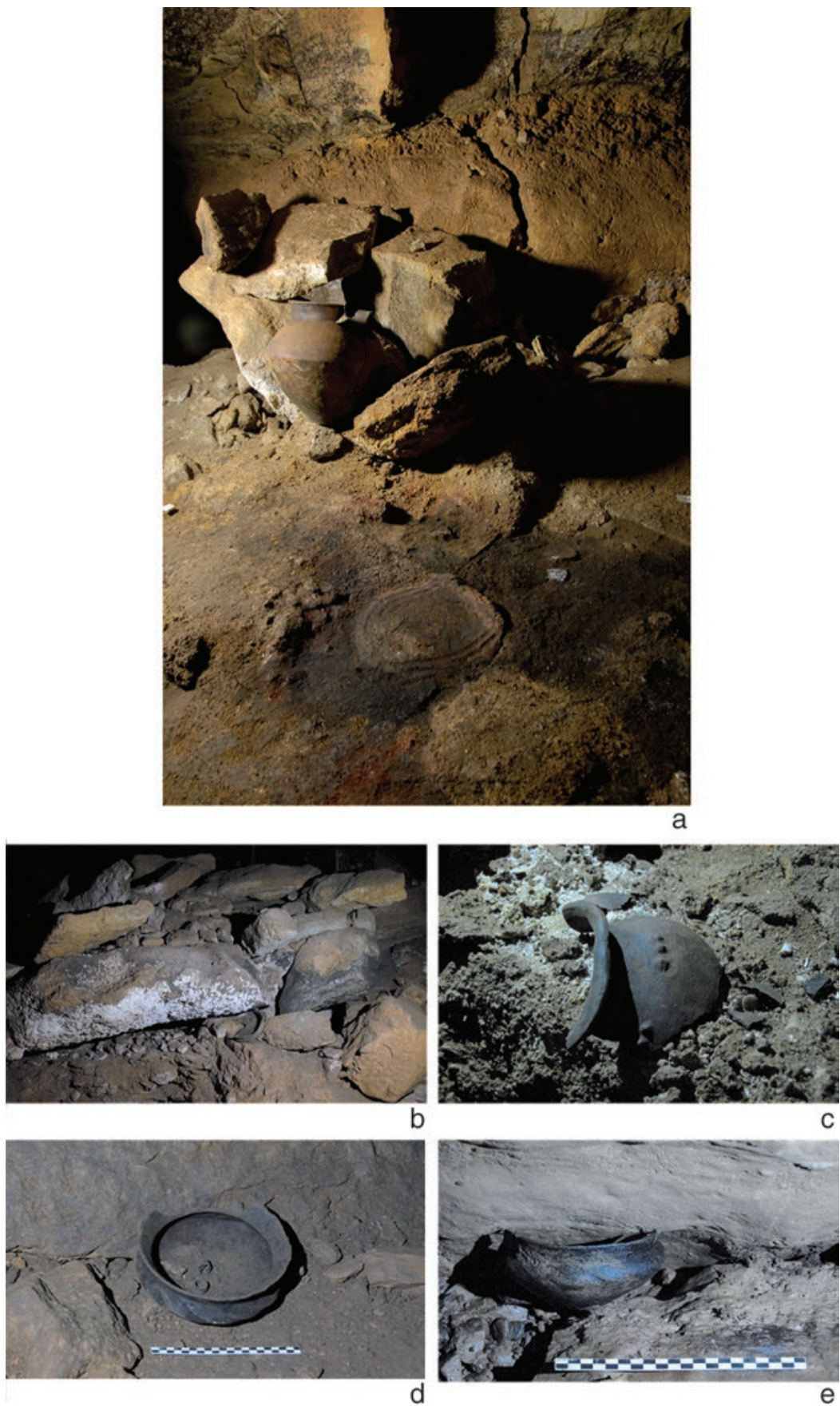

Fig. 9.19 A select range of deposits in the cave: (a, b) Gallery no. 13, (c) Gallery no. 27, (d, e) Gallery no. 18. (Photographs: A. Burens) 
measurements only. As a result, we were unable to undertake any petrographic study or technological analysis which might provide information about the origin of the pots. However, typological analysis suggests that some of the vessels belong to the 'Duffaits Group', dating from the Middle to the beginning of the Late Bronze Age. This corresponds with the outlying 'Tumulus Culture' and the Atlantic Complex (Gomez de Soto 1995, p. 201). Both radiocarbon dating and typological study of the artefacts suggest that votive practices were performed within the cave, together with and disconnected from cave art and domestic activity. In each phase of activity, however, previous deposits and decorated panels were respected and left intact.

\title{
9.7 Conclusion: Residential Activity Versus Cave Art: Towards Overlapping Uses?
}

\author{
According to Tolan-Smith and Bonsall (1997, p. 217-218):
}

\begin{abstract}
'Most researchers concerned with the human use of caves find it convenient to summarize their data in terms of economic or ritual behavior... [and]... When people decide to adopt a sedentary mode of existence they usually come out of their caves and the use of these natural shelters is given over to ritual'. Furthermore, 'the use of cave as theatre for ritual... [is]... usually evidenced by cave art and/or the presence of votive deposits and the use of caves as burial vaults'.
\end{abstract}

The atypical decorated Bronze Age cave of Les Fraux combines cave art with evidence for domestic and symbolic activities, simultaneously but temporarily within two distinct branches of one large underground network, over nearly four centuries. Even if both residential and ritual uses are rarely evidenced simultaneously in the same cave, the diversity of archaeological remains here suggests a plurality of uses, perhaps shifting in time between Middle and Late Bronze Age.

The interpretation of the site is closely linked to the control of time within the cave and is the reason why we developed a contextual approach, taking into account the economic, cultural, topographic and ecological factors of this environment. Difficulties have included a lack of stratigraphy and the absence of direct links between deposits, archaeological sediments and decorated wall panels; at this stage, we have only 14 radiocarbon dates from 5 galleries of the cave. Nevertheless, according to archaeological investigation, the cave appears to have witnessed activity from 1450 to $950 \mathrm{BC}$. Work in progress suggests three periods of activity within this broader date range: a period between the Middle and the Late Bronze Age (from 1450-1250 BC), based on dates from hearth nos. 3, 12 and 14, archaeological deposits and 'torch holes'; a period at the beginning of the Late Bronze Age (around 1250-1125 BC), associated with hearth nos. 8 and 18 and one decorated panel from the gallery no. 18; and finally, a period between about 1200 and $950 \mathrm{BC}$, based on dates from hearth nos. 4 and 19. It comes as no surprise that activity within the cave is more complex than previously thought. One must bear in mind that the cave of 
Les Fraux is unique in Europe. When comparing the site with other French Bronze Age caves, there are several similarities but mainly distinct differences (such as the absence of cave art and the almost systematic presence of funeral activity).

Whilst not conclusive, several possibilities emerge. Evidence for interruptions in the archaeological record between the Middle and Late Bronze Age, combined with the low density of features and other remains within the cave over such a long period of use and the minimal disturbance of older deposits, suggests that activity at the site took the form of numerous short but regular visits over this broader time period. It is worthwhile at this stage to consider that the nature of the various activities may have been very different. The cave may first have been utilised for symbolic activities (cave art, votive deposits, etc.), becoming increasingly used for more domestic activities, with the occasional continuation of some symbolic practices, but with respect for the ancient wall art panels. In order to take these interpretations further, more radiocarbon dates from a wider range of galleries is required, in order to complement the chronological framework based on ceramic typology.

The difficulty lies in the definition and meaning of ritual or symbolic gesture, as practised in a cave context. Our contribution to the study of Norman quarries (Cyril Marcigny pers. comm.) will allow us to compare these two sites, recorded according to the same 3D technology, and will improve our understanding of underground networks by combining the results of archaeological investigations (as 3D simulation) with the benefits of $2.5 \mathrm{D}$ spatial analysis.

Acknowledgements The study of Les Fraux was a planned multi-year archaeological excavation funded by the regional office of Aquitaine of the French Ministry of Culture and Communication. The French National Research Council is also supporting this project, under the umbrella project Global Ecology (SEEG). Thanks also to E. Moisan, V. Léglise and B. Cazalet for their contribution as a part of their training at INSA. Our warmest thanks to Edmond ( $\dagger$ ) and Marcelle Goineaud, owners of the cave Les Fraux, and their daughter, who allowed us to publish images taken in the cave. We would also like to express our sincerest gratitude to Delphine Cross.

\section{References}

Anati, E. (2009). L'art rupestre du Valcamonica: évolution et signification. Une vision panoramique d'après l'état actuel de la recherche. L'Anthropologie, 113, 930-968.

Bahn, P. G. (1997). Dancing in the dark: probing the phenomenon of Pleistocene cave art. In C. Bonsall \& C. Tolan-Smith (Eds.), The human use of caves. British archaeological reports (international series) 667 (pp. 35-37). Oxford: Archaeopress.

Barnatt, J., \& Edmonds, M. (2002). Places apart? Caves and monuments in Neolithic and earlier Bronze Age Britain. Cambridge Archaeological Journal, 12(1), 113-129.

Barrière, C. (1974). Rouffignac: l'archéologie. Travaux de l'Institut d'Art Préhistorique de Toulouse, 16, 3-210.

Barrière, C. (1975). Rouffignac: l'archéologie. Travaux de l'Institut d'Art Préhistorique de Toulouse, 17, 3-83.

Beeching, A., \& Gasco, J. (1989). Les foyers de la préhistoire récente du sud de la France (descriptions, analyses, et essais d'interprétation). In M. Olive \& Y. Taborin (Eds.), Nature et fonction 
des foyers préhistoriques. Actes du colloque international de Nemours (12-13-14 ai 1987). Mémoire du Musée de Préhistoire d'Île de France (pp. 275-292). Nemours: APRAIF.

Brodard, A., Guibert, P., Lévêque, F., Mathé, V., Carozza, L., \& Burens, A. (2012). Thermal characterization of ancient hearths from the cave of Les Fraux (Dordogne, France) by thermoluminescence and magnetic susceptibility measurements. Quaternary Geochronology, 10, 353-358.

Brodard, A., Lacanette-Puyo, D., Guibert, P., Lévêque, F., Burens, A., \& Carozza, L. (2016). A new process of reconstructing archaeological fires from their impact on sediment: a coupled experimental and numerical approach based on the case study of hearths from the cave of Les Fraux (Dordogne, France). Archaeological and Anthropological Sciences, 8(4), 673-687.

Burens, A., Grussenmeyer, P., Carozza, L., Lévêque, F., Guillemin, S., \& Mathé, V. (2014). Benefits of an accurate 3D documentation in understanding the status of the Bronze Age heritage cave "Les Fraux" (France). International Journal of Heritage in the Digital Era, 3(1), 179-195.

Burens-Carozza, A., Grussenmeyer, P., Guillemin, S., Carozza, L., Bourrillon, R., \& Petrognani, S. (2011). Numérisation 3D de la grotte ornée des Fraux, Saint-Martin-de-Fressengeas, Dordogne, France: approche multiscalaire. Images et modèles 3D en milieux naturels. Collection EDYTEM, 12, 183-189.

Carozza, L., Burens, A., Billaud, Y., Ferrulo, O., Bourrillon, R., Petrognani, S., Fritz, C., Tosello, G., Goineaud, E., \& Goineaud, M. (2009). L'horizontal et le vertical: l'âge du Bronze de la grotte des Fraux (Saint-Martin-de-Fressengeas, Dordogne). In D. Fabre (Ed.), De Méditerranée et d'ailleurs... mélanges offerts à Jean Guilaine (pp. 159-172). Tolouse: Archives d'Écologie Préhistorique.

Carpentier, V., Dujardin, L., Marcigny, C., avec Burens, A., Carozza, L., Grussenmeyer, P., Guillemin, S., Mazet, S., \& Vipard, L. (2016). 'Archéologie du refuge' ou de 'l'enfermementvolontaire': la carrière-refuge de la brasserie Saingt à Fleury-sur-Orne (Calvados). Les Nouvelles de l'Archéologie, 143, 59-63.

Clottes, J. (2003). Caves as landscapes. In K. Sognnes (Ed.), Rock art in landscapes: landscapes in rock art (volume 4) (pp. 11-30). Trondheim: Tapir Akademisk.

Dowd, M. A. (2008). The use of caves for funerary and ritual practices in Neolithic Ireland. Antiquity, 82(316), 305-317.

Faulkner, C. H. (1988). Painters of the "dark zone". Archaeology, 41(2), 30-38.

Gasco, J. (2003). Contribution pour une proposition de vocabulaire des structures de combustion. In M.-C. Frère-Sautot (Ed.), Le feu domestique et ses structures au Néolithique et aux Âges des métaux. Actes du colloque de Bourg-en-Bresse et Beaune (7-8 Octobre 2000) (pp. 109-112). Montagnac: Éditions Monique Mergoil.

Gomez de Soto, J. (Ed.). (1980). Les cultures de l'âge du Bronze dans le basin de la Charente. Périgueux: Fanlac.

Gomez de Soto, J. (1995). Le Bronze Moyen en occident: la culture des duffaits et la civilisation des tumulus. L'âge du Bronze en France tome 5. Paris: Picard.

Gómez-Barrera, J. A. (1999). Approche de l'étude des gravures rupestres post-paléolithiques de la péninsule Iberique Préhistoire Ariégeoise, LIV (pp. 265-292).

Grussenmeyer, P., Alby, E., Landes, T., Koehl, M., Guillemin, S., Hullo, J.-F., Assali, P., \& Smigiel, E. (2012). Recording approach of heritage sites based on merging point clouds from high resolution photogrammetry and terrestrial laser scanning. International Archives of the Photogrammetry, Remote Sensing and Spatial Information Sciences, XXXIX-B5, 553-558.

Hameau, P. (2009). Site, support et signe: une cohérence de sens. L'expression graphique picturale au Néolithique. L'Anthropologie, 113, 861-881.

Le Bihan, J.-P., \& Villard, J.-F. (2010). Archéologie d'une île à la pointe de l'Europe: Ouessant. Tome 2: l'habitat de Mez-Notariou des origines à L'âge du Bronze. Saint-Thonan: Centre de recherche archéologique du Finistère.

Lewis-Williams, D. (2002). The mind in the cave. London: Thames \& Hudson.

Moyes, H. (2012). Introduction. In H. Moyes (Ed.), Sacred darkness: A global perspective on the ritual uses of caves (pp. 1-14). Boulder: University Press of Colorado. 


\section{Editor's Proof}

Otte, M., David-Elbiali, M., Eluère, C., \& Mohen, J.-P. (2002). La protohistoire. Bruxelles: De Boeck Université.

Pataux, A. (2010). Cour blanc, ventre blanc: fétiches et féticheurs. Montreuil: Gourcuff Gradenigo. Petrognani, S., Bourrillon, R., Burens, A., \& Carozza, L. (2014). À la poursuite du temps court: les expressions pariétales de l'âge du Bronze de la grotte des Fraux (Dordogne). In P. Paillet (Ed.), Les arts de la Préhistoire: micro-analyses, mises en contextes et conservation. Actes du colloque 'micro-analyses et datations de l'art préhistorique dans son contexte archéologique', MADAPCA, Paris, 16-18 Novembre 2011. PALEO, numéro special (pp. 163-169).

Quiles, A., Valladas, H., Bocherens, H., Delque-Kolickoli kolic, E., Kaltnecker, E., van der Plichtf, J., Delannoy, J.-J., Feruglio, V., Fritz, C., Monney, J., Philippe, M., Tosello, G., Clottes, J., \& Geneste, J.-M. (2016). A high-precision chronological model for the decorated Upper Paleolithic cave of Chauvet-Pont d'Arc, Ardèche, France. Proceedings of the National Academy of Sciences, 113(17), 4670-4675.

Reznikoff, I., \& Dauvois, M. (1988). La dimension sonore des grottes ornées. Bulletin de la Société Préhistorique Française, 85(8), 238-246.

Sieveking, A. (1997). Cave as context in Palaeolithic art. In C. Bonsall \& C. Tolan-Smith (Eds.), The human use of caves. British archaeological reports (international series) 667 (pp. 25-34). Oxford: Archaeopress.

Tolan-Smith, C., \& Bonsall, C. (1997). The human use of caves. In C. Bonsall \& C. Tolan-Smith (Eds.), The human use of caves. British archaeological reports (international series) 667 (pp. 217-218). Oxford: Archaeopress.

Walker, W. H. (1995). Ceremonial trash? In J. M. Skibo, W. H. Walker, \& A. E. Nielsen (Eds.), Expanding archaeology (pp. 67-79). Salt Lake City: University of Utah Press.

Wylie, A. (1985). The reaction against analogy. In Advances in Archaeological Method and Theory (Vol. 8, pp. 63-111). 